\title{
Diseases of flounder Platichthys flesus in Dutch coastal and estuarine waters, with particular reference to environmental stress factors. II. Liver histopathology
}

\author{
A. D. Vethaak ${ }^{1, *}$, P. W. Wester ${ }^{2}$ \\ ${ }^{1}$ Ministry of Transport, Public Works and Water Management, Directorate-General for Public Works and Water Management, \\ National Institute for Coastal and Marine Management/RIKZ, Ecotoxicology Section, PO Box 8039, 4330 EA Middelburg, \\ The Netherlands \\ ${ }^{2}$ National Institute of Public Health and Environmental Protecton (RIVM), Laboratory for Pathology, PO Box 1 , \\ 3720 BA Bilthoven, The Netherlands
}

\begin{abstract}
This paper reports the detailed histopathological analysis of livers of flounder Platichthys flesus sampled in Dutch coastal and estuarine waters during 1985-89. In conjunction with an epizootiological study of grossly identifiable diseases at 10 sampling locations, a total of 210 livers $11 \%$ of sampled population) showing gross nodular lesions (diameter $>2 \mathrm{~mm}$ ) and 315 livers showing no gross pathology were collected. Of the 210 livers with grossly observable nodules, $67 \%$ were diagnosed as having neoplasms. The majority of these neoplasms were identified as hepatocellular adenoma; $13.1 \%$ were diagnosed as hepatocellular carcinoma. Most of the remaining nodules were diagnosed as foci of cellular alteration, which are considered to be preneoplastic lesions. Routine histopathological examination of livers showing no gross pathology resulted in the identification of a range of lesions including hepatocellular adenoma, foci of cellular alteration, hydropic vacuolization of biliary epithelial cells and hepatocytes, inflammatory lesions, focal necrosis, regenerative foci, and fibrillar hepatocytes of unknown significance. In addition, indices were used to quantify the presence of storage vacuoles (glycogen and lipid) and the relative density of melanomacrophage centres. The results indicate that a small proportion of neoplasms would be missed if only livers with grossly detectable nodules were subjected to histological examination. The prevalence of foci of cellular alteration at the different sampling sites showed a good correspondence with that of neoplasms, providing support for the hypothesis that these conditions represent stages of the same process. Of the other lesions and quantitative indices, only hydropic vacuolization of bilhary epithelial cells had a spatial distribution similar to that of neoplasms. It is concluded that liver neoplasms and especially their precursor lesions in flounder are promising tools for monitoring exposure to potential carcinogens, provided that migration patterns are explicitly taken into account. Furthermore, experimental studies are needed to investigate the chemical agents responsible for the onset of these early lesions and their progression into neoplasms, and also to evaluate the contribution of other environmental and host-related factors.
\end{abstract}

KEY WORDS: Flatfish · Liver neoplasia - Marine pollution - Disease monitoring

\section{INTRODUCTION}

Flounder Platichthys flesus spawn in offshore areas but grow up and feed in inshore coastal waters, estuaries and fresh water. After spawning in winter

\footnotetext{
•E-mail: vethaak@rikz.rws.minvenw.nl
}

they usually return to the same inshore feeding areas as in previous years, and move little during the summer (De Veen 1971). In conjunction with their abundance, widespread distribution, and susceptibility to disease, this tendency to remain faithful to the same feeding areas makes flounder suitable for studies of disease in relation to pollution (Vethaak 1992a, Vethaak \& Jol 1996). 
A previous paper has described the epizootiological characteristics of gross lesions in flounder from Dutch coastal and estuarine waters during 1983-89 (Vethaak \& Jol 1996). In that study, the gross lesions included in addition to 2 epidermal diseases - visible nodules (>2 $\mathrm{mm}$ in diameter) on the liver surface, which were histologically confirmed as neoplasms. It was shown that neoplastic nodules were present in $1.0 \%$ of all flounder aged $2+y r$, prevalences rising steeply with age and locally attaining values of $30 \%$ in fish aged $6+\mathrm{yr}$ (Vethaak \& Jol 1996). An attempt was made to relate prevalences of these lesions to environmental pollution. Taking the data set as a whole, there were no significant correlations between the observed spatial variation in the occurrence of these nodules and concentrations of selected contaminants in sediments (Flg. 1) or tish liver tissue. Neoplasms were virtually absent in flounder from highly polluted brackish areas. This may be at least partially attributable to the fact that young fish (2 to $3 \mathrm{yr}$ old) formed a high proportion of the populations inhabiting these brackish polluted sites, while neoplasms are typically found in fish of 6 or more years of age. Only limited indications were found for a direct chemical aetiology, with particularly high prevalences at one site (Site 6) close to an iron works: younger age groups were notably affected at this site. Seasonal and year-to-year variation in the prevalence of liver neo-

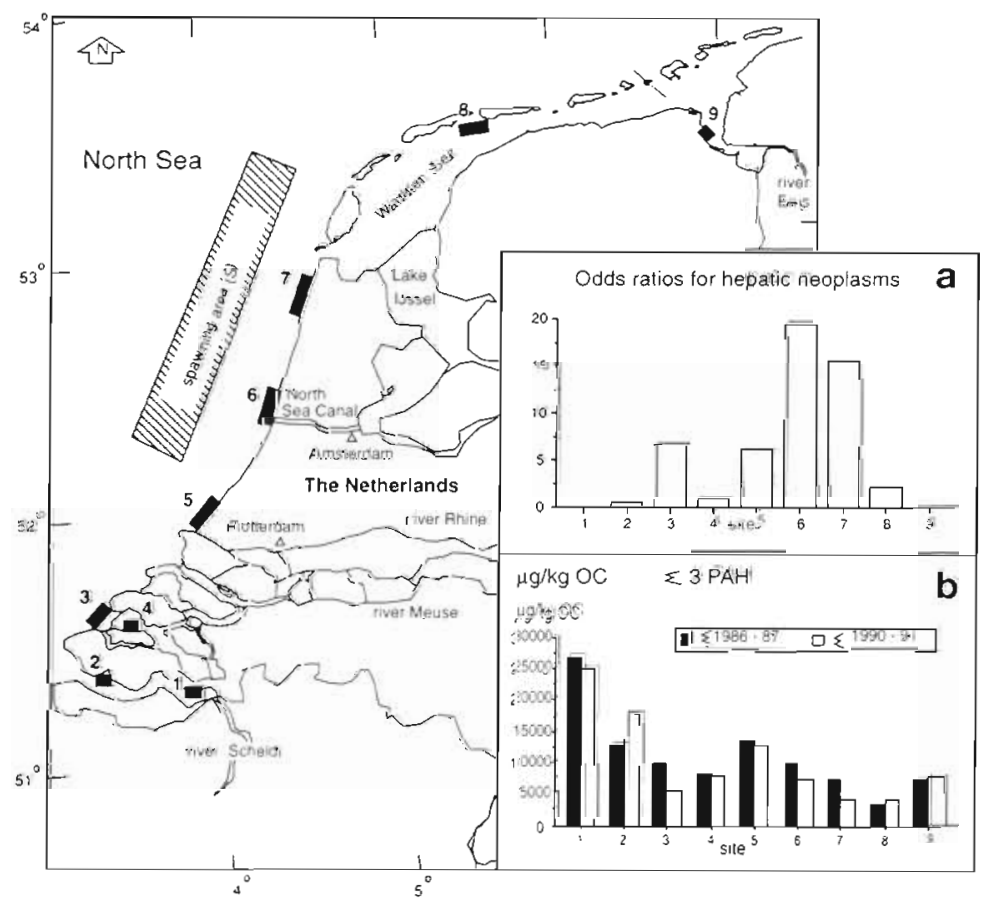

Fig. 1. Map of the study area showing sampling locations (Sites $1-9$ and Area S). Also shown (from Vethaak \& Jol 1996) are: (a) odds ratios for hepatic neoplasms at Sites 1-9 adjusted for sampling year/tish length; (b) concentrations of the sum of 3 PAHs [benz(b)fluoranthene, benz(k)fluoranthene, benz(a)pyrenel in sediments at Sites 1-9 on 2 separate sampling occasions plasms was also found, and it was concluded that observed patterns of this disease could not be explained by simple local causal factors and that age-related migration should be taken into account.

The present paper deals with the histopathological interpretation of liver nodules detected during gross inspection of fish from the above epizootiological surveys. It also presents data - from the same sampleson an additional histopathological investigation of livers lacking nodules. The purpose of the latter investigation was to provide general background information on liver histology, as well as to complement the findings relating to liver nodules.

\section{MATERIALS AND MEIHUDS}

Study area and sampling procedure. Late summer sampling: Between 1985 and 1989 flounder were collected during September from polluted coastal waters (Sites 5 and 6) and from the Eastern Scheldt (Site 4). Site 4 was adopted as a reference site because of relatively low pollution levels. During 1987-89 the programme was extended to include 6 additional sites: 2 in coastal waters (Sites 3 and 7) 1 in the Wadden sea (Site 8) and a further 3 in 2 different estuaries, the Western Scheldt (Sites 1 and 2) and the Ems-Dollard (Site 9) (Fig. 1).

Late winter sampling: In 1988 and 1989. additional sampling was conducted during February-April in an offshore coastal spawning area (Area S). The population sampled is considered to represent, at least in part, the various populations sampled during late summer.

Information about the sampling methods and a detailed characterization of the sampling sites are given by Vethaak \& Jol (1996).

A total of 14526 livers of flounder were inspected for the presence of grossly visible liver nodules: a total of 210 livers with nodular lesions greater than $2 \mathrm{~mm}$ in diameter were collected for further investigation. In addition, a total of 315 livers without nodules were collected during September 1987 (280 fish at 9 sites) and February-April 1988 (35 fish in Area S). These samples were taken at random within defined length classes (Table 1). At each site an attempt was made to sample 10 fish in each of 3 length classes and an additional 5 fish in the largest length class. However, due to the scarcity of small fish at Sites 3 and 6 and in Area S, and the scarcity of large fish at Site 9 , this schedule could not be adhered to exactly. 
Table 1 Platichthys flesus. Number of livers examined for routine histopathology at the 9 sampling sites (Sites 1-9) and the spawning area (S). Fish with liver nodules were excluded

\begin{tabular}{|c|c|c|c|c|c|c|c|}
\hline Season & Site & Year & $\begin{array}{l}\text { Total no. } \\
\text { of fish }\end{array}$ & \multicolumn{4}{|c|}{ Length class $(\mathrm{cm})$} \\
\hline \multirow[t]{10}{*}{ Late summer } & 1 & 1987 & 35 & 10 & 10 & 10 & 5 \\
\hline & 2 & 1987 & 35 & 10 & 10 & 10 & 5 \\
\hline & 3 & 1987 & 25 & 0 & 10 & 10 & 5 \\
\hline & 4 & 1987 & 35 & 10 & 10 & 10 & 5 \\
\hline & 5 & 1987 & 35 & 10 & 10 & 10 & 5 \\
\hline & 6 & 1987 & 25 & 0 & 10 & 10 & 5 \\
\hline & 7 & 1987 & 35 & 10 & 10 & 10 & 5 \\
\hline & 8 & 1987 & 35 & 10 & 10 & 10 & 5 \\
\hline & 9 & 1987 & 20 & 10 & 10 & 0 & 0 \\
\hline & Total & & 280 & 70 & 90 & 80 & 40 \\
\hline Late winter & $\mathrm{S}$ & 1988 & 35 & 0 & 14 & 14 & 7 \\
\hline All sites + seasons & $1-9+S$ & $1987-88$ & 315 & 70 & 104 & 94 & 47 \\
\hline
\end{tabular}

Statistical methods. The data for foci of cellular alteration and inflammatory lesions were analysed by fitting a loglinear model (logit analysis) with length and site as explanatory variables. Data from the 2 largest length groups were pooled. Data on the occurrence of hydropic vacuolization of biliary cells, hepatocellular hypervacuolization, focal necrosis and regenerative foci were not analysed with this model because there were insufficient numbers of diseased fish. For similar reasons, no statistical analysis of lengthto-age-transformed data for the various lesions was carried out.

The methodalogy of the log-linear model is described at length by Vethaak \& Jol (1996). Odds ratios were

The length and sex of each fish were recorded. The otoliths were removed for age determination according to the methods of Van Leeuwen \& Vethaak (1988).

Histological techniques. All 525 livers collected were preserved in 10\% saline formalin or Bouin's solution for histological examination. Fixed tissues were routinely processed to paraffin wax blocks. Sections were then cut at 3 to $5 \mu \mathrm{m}$ and stained primarily with haematoxylin and eosin (H\&E). The Oil-Red-O (O-Red-O) reaction for staining of lipids was applied to frozen cryostat sections. Additional histochemical stains were used where necessary and where possible to further investigate specific lesions in more detail.

Routinely, only a single section per liver was cut. However, on the infrequent occasions when histological examination indicated that the section had missed a grossly observed nodule, further sections were cut and/or the remaining fixed material was re-examined.

For semi-quantification of storage products (fat or glycogen) in the form of cytoplasmic vacuoles in the liver, an index was formulated as follows:

$1=$ no vacuolization; $2=$ up to $25 \%$ of the cytoplasm vacuolated; $3=25$ to $75 \%$ of the cytoplasm vacuolated; $4=$ near-total vacuolization, with increased cytoplasmic volume.

Similar semi-quantification was performed for the density of melanomacrophage centres (MMCs):

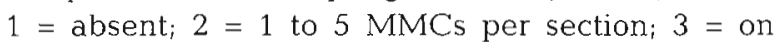
average, $1 \mathrm{MMC}$ per field of view (mag. $10 \times 25$ ); $4=$ several MMCs per field of view (mag. $10 \times 25$ ).

The investigation of liver abnormalities was confined to histological examination of paraffin-embedded tissues. Because of the large number of fish sampled and the suboptimal conditions for laboratory work while at sea, other techniques such as enzyme histochemistry or electron microscopy were not attempted. estimated from the parameter coefficients of the logit analysis. Odds ratios for site were expressed relative to Site 4 (reference site), and for length relative to the smallest group $(20-29.9 \mathrm{~cm})$.

Correlations between disease occurrence [log(disease odds)] and contaminant levels in fish liver and sediment detailled in Vethaak \& Jol (1996) were tested by simple regression analysis. Correlations with liver contaminant concentrations were tested using data from small flounder sampled in September 1987. Correlations with sediment contaminant concentrations were tested using data for the fraction $<63 \mu \mathrm{m}$ in samples collected in 1986-87.

Patterns of co-occurrence of different lesions in the livers of individual flounder were determined by testing for independence of pairs of lesion types using $2 \times 2$ contingency tables. Probabilities were determined for log-likelihood ratios using Yates' corrected test for small sample sizes. Because of the small number of cases of most types of lesions, only 2-way tables were used. The significance level of the critical chivalue was set at $\mathrm{p}<0.05$.

\section{RESULTS}

\section{Histology of the normal liver}

The normal liver morphology of flounder is not fundamentally different from that of other fish species described in the literature (e.g. Myers et al. 1987, Hinton \& Laurén 1990, Hinton 1994). The functional unit in the fish liver is a tubule with a central bile canaliculus (or bile ductule), with individual tubules incompletely separated by sinusoids (Hinton \& Laurén 1990, Hinton 1994). Pancreatic exocrine tissue is scat- 


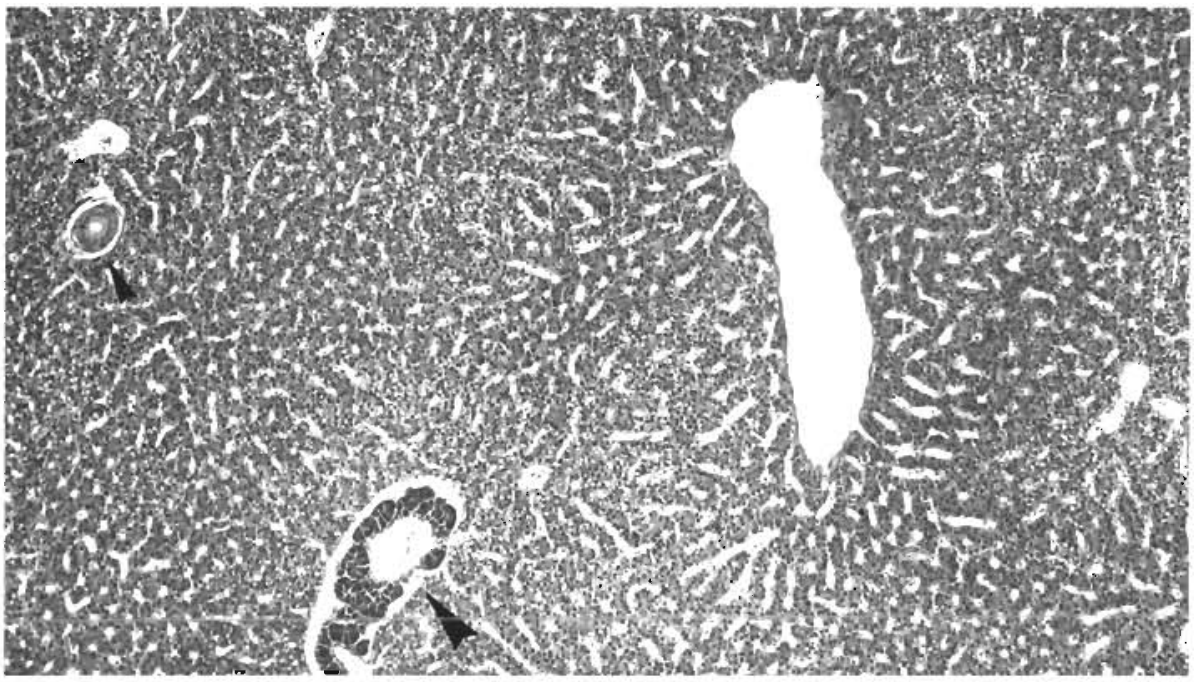

Fig. 2. Platichthys flesus. Histological section of a normal flounder liver. Note bile duct (small arrowhead), exocrine pancreatic tissue (large arrowhead) and tubulosinusoidal architecture without lobular structures. There is uniform sliqht vacuolization, indicative of glycogen storage. $H \& E_{1} \times 32$ tered throughout the liver, with a more or less regular distribution (Fig. 2); for this reason the liver is also termed the 'hepatopancreas'. Randomly distributed bile ducts appear as tubular structures formed by cuboidal epithelium surrounded by a connective tissue sheath of variable thickness. The height of the epithelium and corresponding thickness of the fibrous sheath are apparently related to location within the biliary tree. A lobular pattern of liver architecture, as common in higher vertebrates, is lacking. Clusters of swollen melanomacrophage centres (MMCs) can be found scattered throughout the liver. Their content can vary from faintly staining foamy material to brown or black pigmented storage products. These MMCs, also referred to as macrophage aggregates (Wolke 1992), are generally regarded, in part, to function within the non-specific cell-mediated immune system. Through phagocytotic activity, they represent sites of accumulation and storage of waste products, and, depending on their degree of pigmentation (Wolke et al. 1985), can thus reflect both the age and the health. status of the fish (Agius \& Agbede 1984).

Variability of the hepatocyte morphology depends partly on the reproductive cycle, in particular the estrogen-induced state of vitellogenesis in spawning females, and also on the quantity of storage products such as fat and glycogen. The amount of storage products obviously depends on the quality and quantity of the food supply. In routine histological sections, both fat and glycogen are seen as translucent cytoplasmic areas. Although in general glycogen is more lacy in appearance and more diffusely distributed through the cytoplasm than fat (lipid), which is manifest as globular droplets, it is not always possible to discriminate between these materials in routine sections. It is our impression that the accumulation of fatty droplets is not necessarily indicative of cellular degeneration or fatty degeneration, or of fatty change or steatosis, as is frequently the case in mammalian liver pathology.

\section{Liver histopathology}

Liver abnormalities were broadly classified into neoplastic and putative preneoplastic lesions on the one hand, and nonneoplastic lesions on the other. The latter group included inflammatory and necrotic lesions; abnormalities related to storage products could belong to either group.

\section{Neoplastic and putative preneoplastic lesions}

These lesions were grouped into the following 3 categories based on studies of other fish species such as rainbow trout Salmo gairdneri (Hendricks et al. 1984), winter flounder Pleuronectes americanus (Moore et al. 1989) and English sole Pleuronectes vetulus (Myers et al, 1987), and of rodents (Frith \& Ward 1980 , Maronpot et al. 1986).

Foci of cellular alteration. These include distinct focal areas within which the hepatocytes contain different amounts of cytoplasmic components, and hence demonstrate a different degree of staining compared to the surrounding parenchyma. This altered staining may be eosinophilic (eosinophilic focus), basophilic (basophilic focus), or translucent (clear cell focus), depending on the variation in distribution of cytoplasmic organelles and/or storage material (Fig. $3 \mathrm{a}-\mathrm{c}$ ). In other respects the architecture remains normal, without compression of the surrounding tissue. In the present study, a particularly large focal lesion, in the literature sometimes referred to as an 'area of cellular alteration', was also included in this category. 

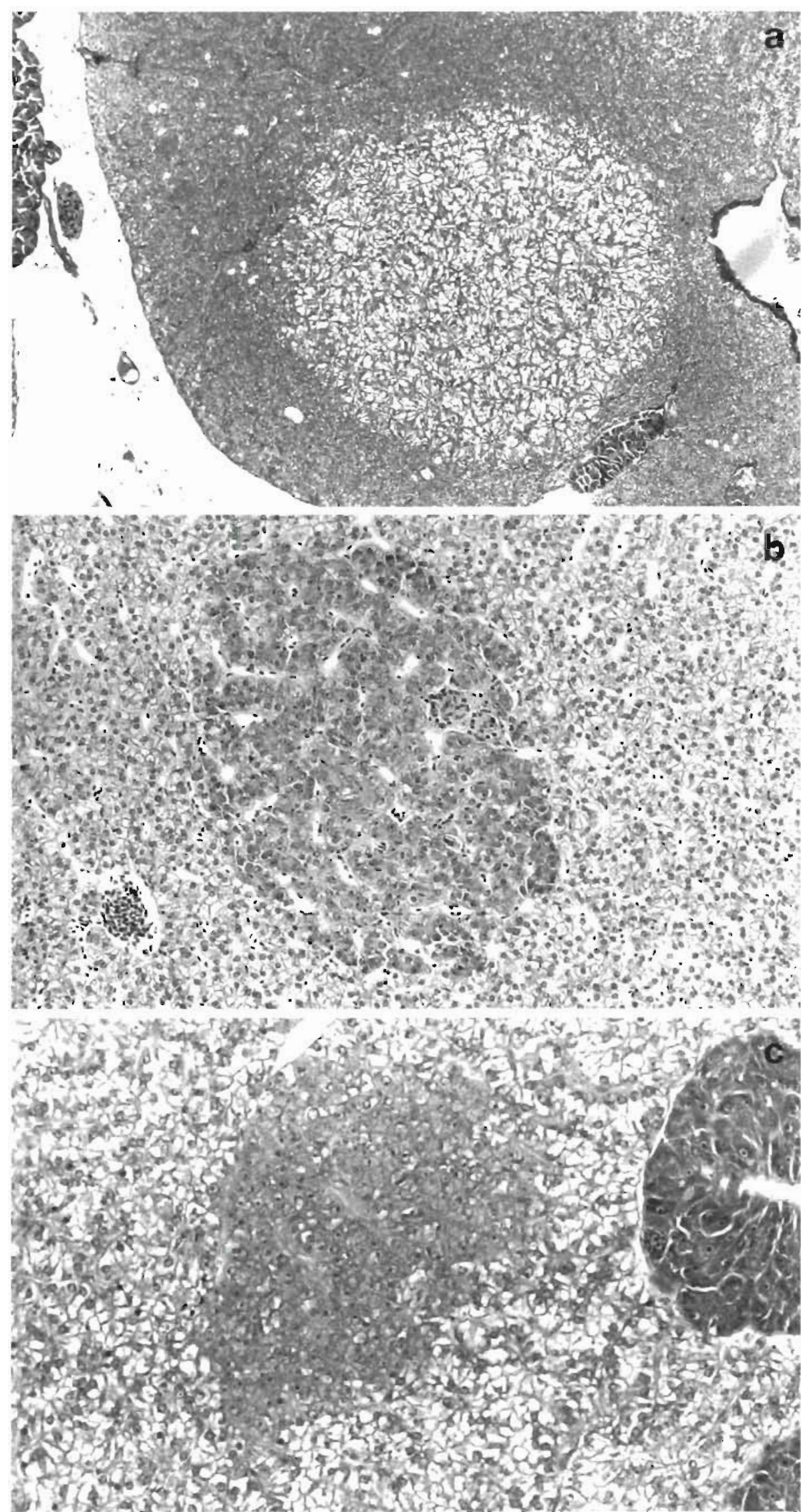

Fig. 3. Platichthys flesus. Histological section of a flounder liver showing foci of cellular alteration (a) clear cell focus, $\times 80$; (b) baso philic focus, $\times 160$; (c) eosinophilic focus, $\times 200$. Note absence of com pression and maintenance of nor mal architectural pattern. H\&E 
The most commonly encountered type of focus of cellular alteration in the sections examined was the clear cell tocus ( $58 \%$ of foci), consisting of cells with a higher cytoplasmic fat and/or glycogen content than the surrounding liver cells Basophulic focl were somewhat less common (39\%), while eosinophilıc focl were scarce $(3 \%)$. Some of the basophulıc foci may have been regenerative foci, the difference between them being, in our material, difficult to establish due to the virtual absence of associated liver damage. In the livers of flounder sampled in late winter, however, the difference was more obvious due to an association of regenerative foci with focal necrosis and inflammation.

Hepatocellular adenoma. This is considered to be a benign neoplasm, and is characterized as a nodular hyperplastic hepatocellular lesion, showing compression and slightly altered cytomorphology and architecture The absence of pancreatic tissue, of MMCs (shown up by PAS staining), and of cytoplasmic Iron storage (Perls' Prussian Blue staining) are useful diagnostıc features (Fig. 4a, b)

Hepatocellular carcinoma. In mammalian pathology, a carcinoma is a malignant epithelial tumour with potentially lethal effects via invasion and metastatic spread. Although these lethal characteristics are exceedingly rare in fish and therefore difficult to apply, this dragnosis is used in the present study for those neoplasms showing advanced cellular atypia and architectural abnormalities such as a tubular, acinar or solid growth pattern (Fig. 5a). In addition, local invasıon was used as a supporting criterion (Fig. 5b)

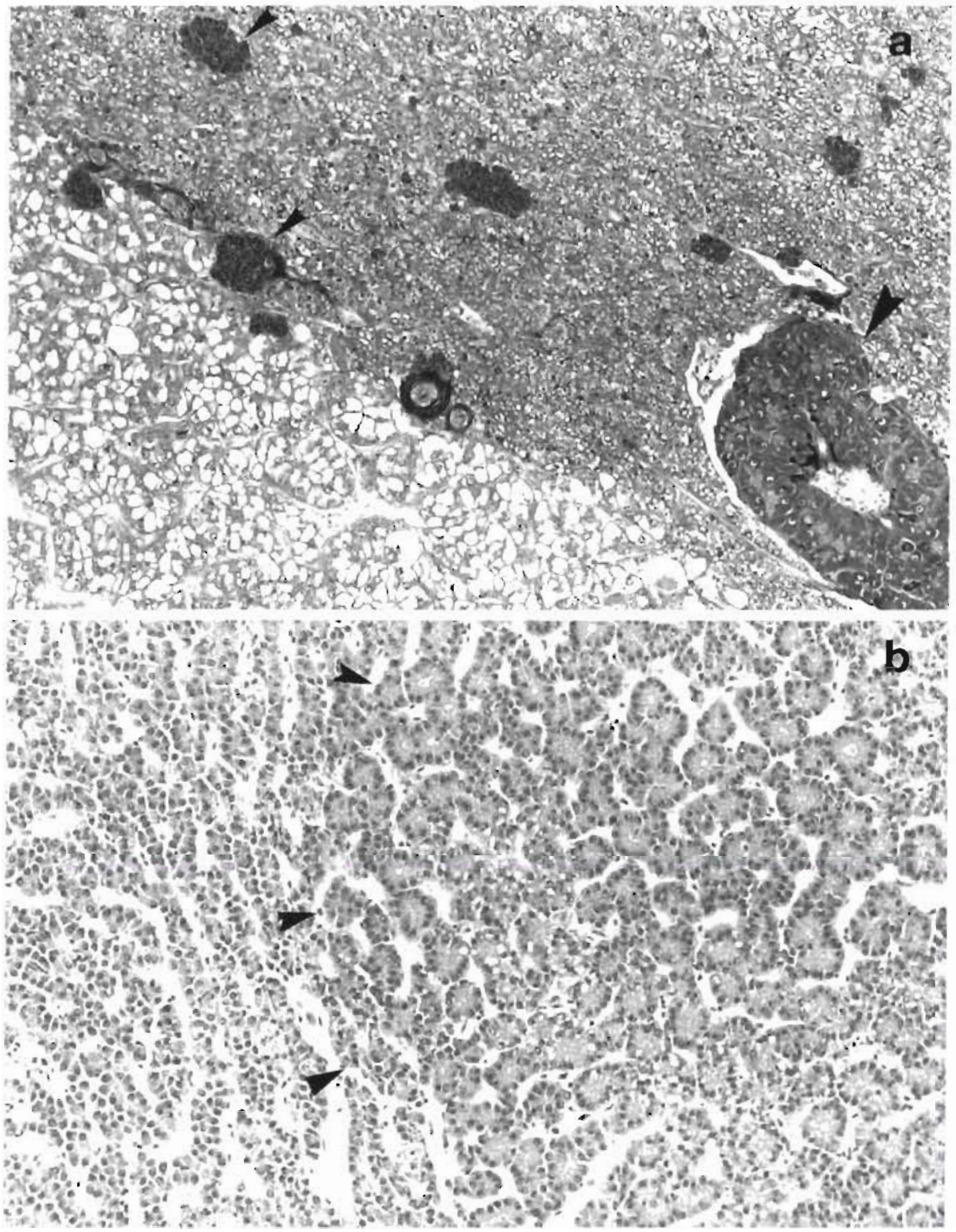

Fig. 4. Platichthys flesus. (a) Liver with nodular lesion (lower left) diagnosed as hepatocellular adenoma, showing obvious compression and clear demarcation from surrounding tissue, but with nearnormal cytomorphology. Note the presence in normal tissue, but not in neoplastic liver tissue, of PAS-positive melanomacrophage centres (small arrowhead) and exocrine pancreatic tissue (large arrowhead). PAS, $\times 160$. (b) Detailed view of a hepatocellular adenoma (right). Note trabecular pattern and compression of the surrounding liver, and acinar architecture in the neoplastic component (arrowheads indicate the boundary between normal and tumourous tissue). $H \& E_{1} \times 160$ 
In many severely affected fish, multiple lesıons were commonly detected. Carcinomas and adenomas frequently occurred in combination with each other and/or with foci of cellular alteration

\section{Nonneoplastic lesions}

Storage disorders. As reported above, the cytomorphology of the liver shows considerable vamation and hence it is difficult to declare that an observed condition related to the deposition of storage products is pathological. In the case of lipid/glycogen storage, an apparently zonal distribution of vacuoles (Fig. 6a) or a gradual alteration in density (Fig 6b) sometımes occurred in apparently normal livers (Fig. 6). Clear-cell focl were only recorded as such if they were restricted to a specific area and showed obvious margins Although they could be considered focal storage disorders, we followed the example of previous authors (e g Myers et al. 1987) and classified them as focl of cellular alteration as above.

Inflammatory lesions Two major categories of inflammatory-related lesıons were recognized in our material.

Parasitic lesions and cysts. These were lesions containing parasites or their remains, principally nematodes, together with extensive necrosis and an inflammatory response (Fig. 7). Parasitic cysts often contaned the spores of the protozoan Glugea sp. In general, the inflammatory response was minımal around these cysts

Fig. 5. Platichthys flesus. (a) Hepatocellular carcinoma, showing abnormal architecture with solid growth and multiple perivascular cystic spaces. Note also capsular invasion and lack of pancreatic tissue. H\&E, $\times 16$. (b) Hepatocellular carcinoma (top) with local invasion in glycogen-rich normal liver (large arrowheads). Note irregular architecture and orientation of hepatocytes and accompanying inflammatory response

(small arrowhead). H\&E, $\times 160$

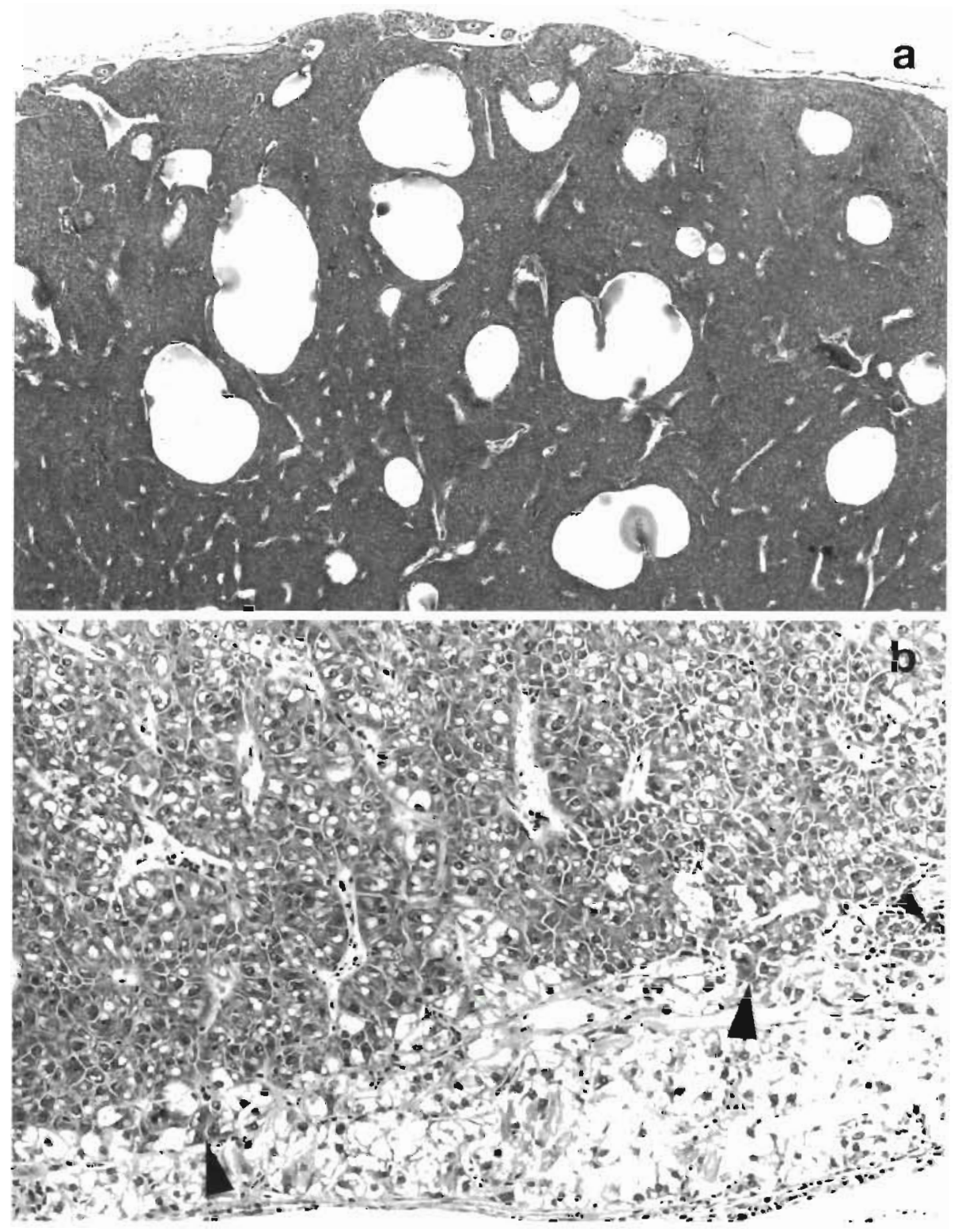




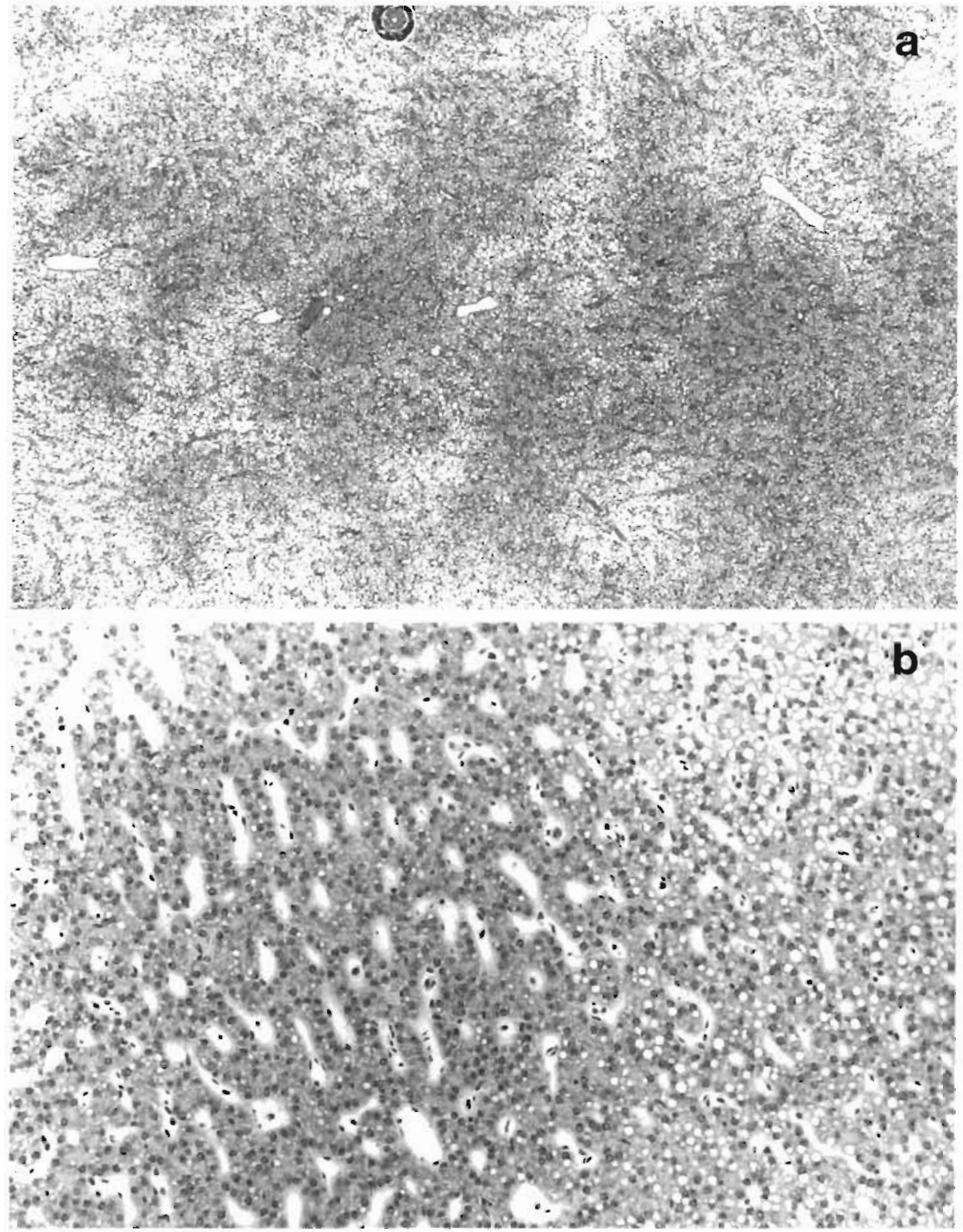

Fig. 6. Platichthys flesus. Normal flounder livers with (a) seemingly zonal distribution of vacuolization; $H \& E, \times 48$; and (b) a gradual alteration in density of vacuolization; H\&E, $\times 160$
Hepatitıs: Accumulations of inflammatory cells llymphocytes and macrophages), without visıble associated microorganisms, were frequently encountered on the surface of the liver or in close proximity to major blood vessels (Fig 8, serosal inflammation) In flounder captured in late winter this inflammation occurred more diffusely throughout the liver (Fig 9; hepatitis).

Miscellaneous nonneoplastic lesions.

Hydropic vacuolization of biliary epithelıal cells: This lesion was characterized by marked cytoplasmic swelling of groups of cells in which there was an increase in translucency of the cytoplasmic compounds. These cells were arranged in tubular profiles Because these 'vacuolated' cells were within biliary tracts and were often surrounded by a thin fibrous capsule (Fig 10), they were considered to primarlly affect biliary epithel.1al cells. In some cases, scattered isolated cells were affected which presumably represented single preductular blhary epithelial cells within the centre of the hepatic tubule. In general, hydropic vacuolization of bllary epithellal cells was diffusely distributed throughout the liver.

Focal hepatocellular hypervacuolization: In a few isolated cases, single hepatocytes or groups of hepatocytes showed excessive swelling, and occasional pyknotic nucles were seen (Fig. 11). The pathological significance of this probably degenerative storage disorder is unknown. Stanning of this material with $\mathrm{O}$-Red-O and PAS gave negative results.

Hydropic vacuolization of biliary epithelial cells and focal hepatocellular hypervacuolization, which we consider to be hydropic degenerative lesions, are 
Fig. 7. Platichthys flesus. Liver with subcapsular protruding lesion containing, in the centre, a parasitic nema:ode, surrounded by macrophages and a fibrous capsule. $H \& E, \times 80$

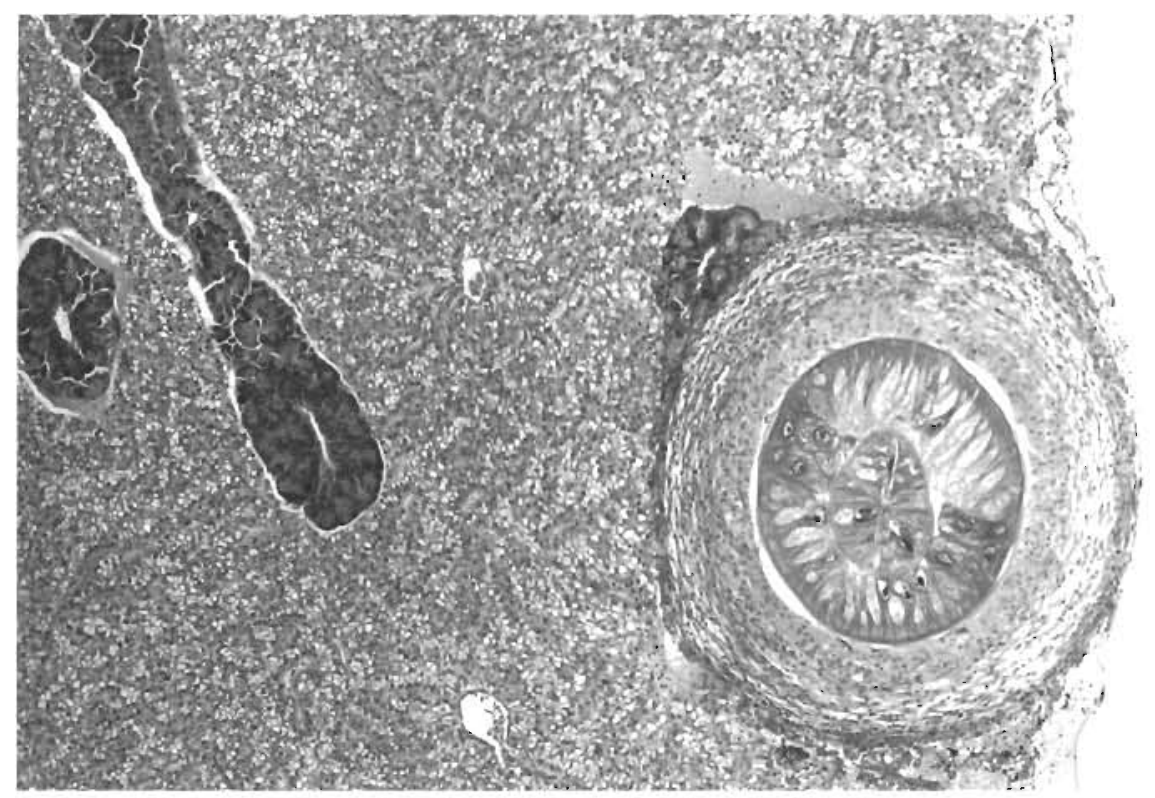

thought to be separate entities and are discrimmated from each other and from clear-cell focl on the basis of the characteristics given in Table 2

Focal necrosis: Occasionally, focal necrosis was found. Since agonal or postmortem liver damage was a frequent finding despite all efforts to handle animals and tissues carefully, it was necessary to differentiate this (autolysis) condition from (intra-vital) necrosis. Only when an associated tissue response (FIg 12) was apparent, was focal necrosis diagnosed

Regenerative foci: Regenerative focl were found mainly in flounder captured in late winter, where inflammation or necrosis was apparent. These tocl consisted of small irregular groups of small basophilic cells with hyperchromatic nuclei (Fig 13)

Fibrillar hepatocytes. In some livers, hepatocytes were found to contain a stack of long parallel fibrils in the cytoplasm, giving the cell a columnar or wedgeshaped appearance ( $\mathrm{F} l \mathrm{~g}$ 14) Unfortunately, the nature of these fibrils could not be determined, as fixation of the materral was not considered adequate for examsnation by electron microscopy. This condition bore no apparent relation to the any of the above pathological conditions.
Fig. 8. Platichthys flesus. Liver with serosal inflammation. H\&E,

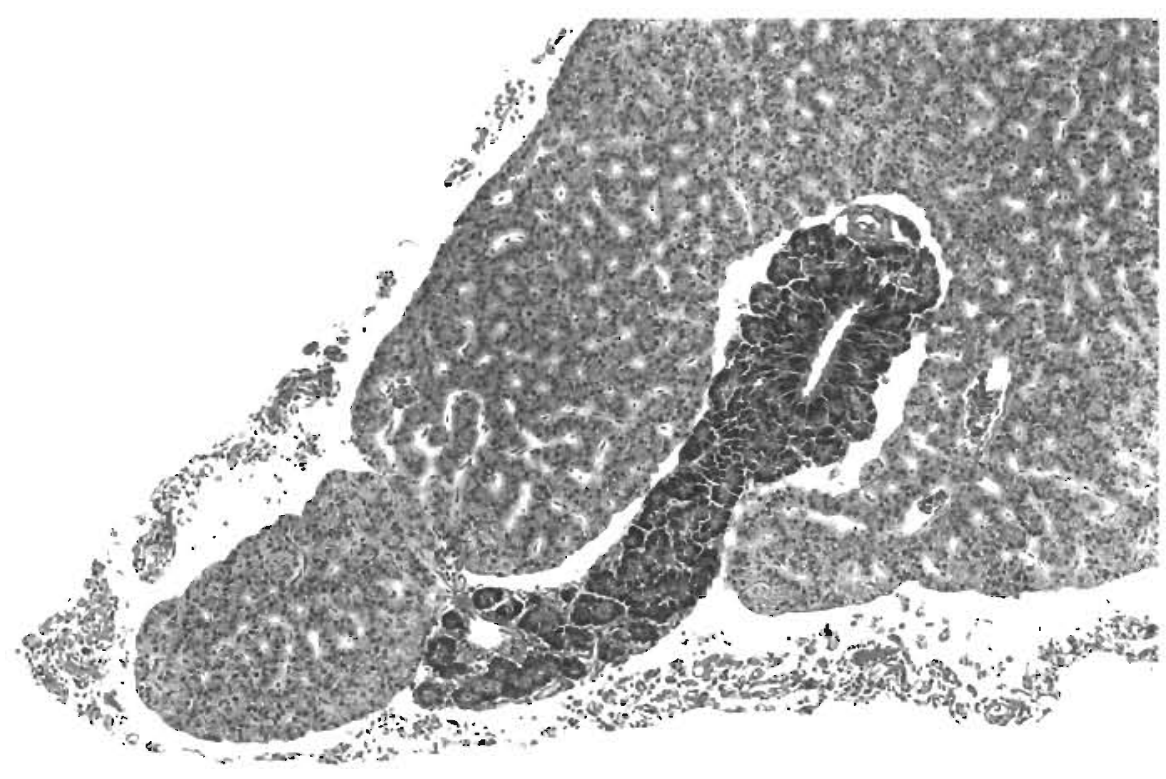




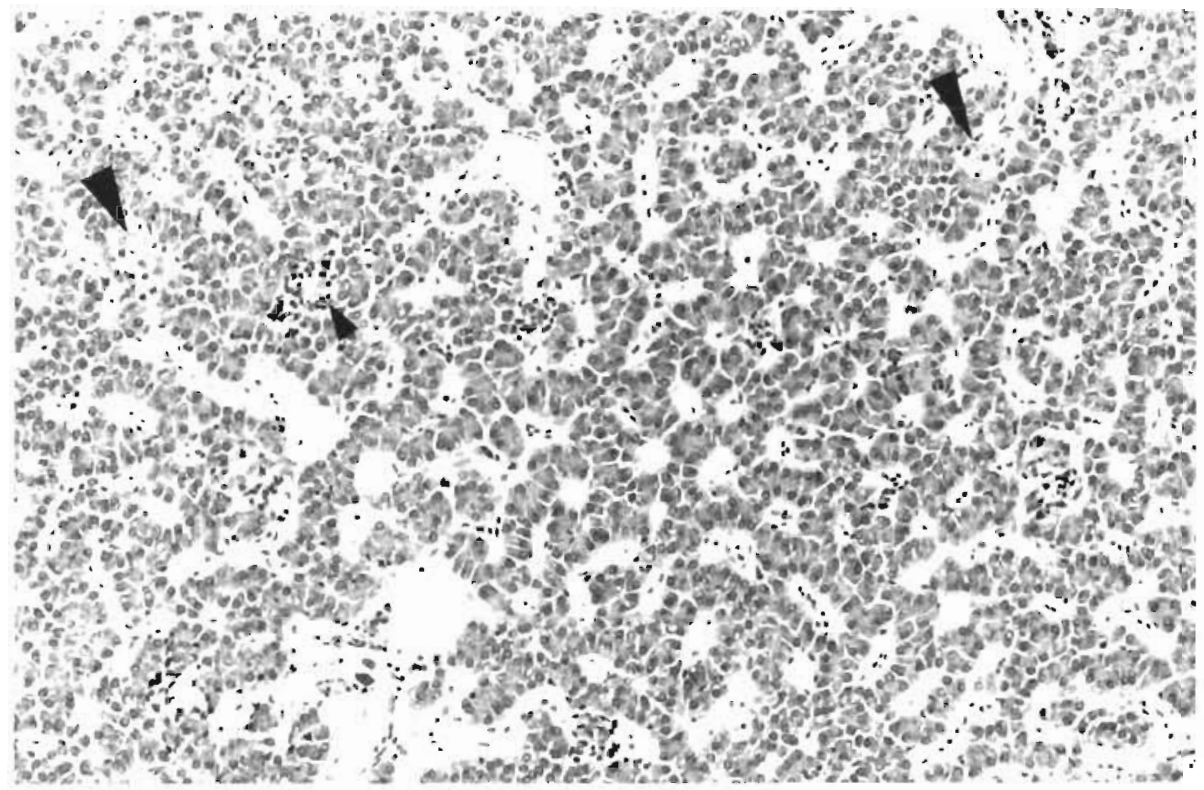

Fig. 9. Platichthys flesus. Atrophic floumiter liver from late winter with diffuse accumulation of inflammatory cells (hepatitis) (small arrowhead) and small melanomacrophage centres (large arrowheads). $H \& E, \times 160$

\section{Histological confirmation of gross liver lesions}

In Table 3 the spatial and seasonal distributions of grossly visible nodules and histologically confurmed hepatıc neoplasms are presented. Since the occurrence of liver neoplasms appears to be related to length, age and sex of the fish (Vethaak \& Jol 1996) the crude prevalences in this table only give a general impression of the differences among sites and seasons (see also Fig 1a) A detalled statıstıcal analysis is given by Vethaak \& Jol (1996). The principal features of the data are as follows:

- Of the 210 grossly detected liver nodules, 141 (67.1\%) were diagnosed as neoplasms.
- The 141 neoplasms included 117 cases of hepatocellular adenomas and 19 of hepatocellular carcinomas, 4 cases of cholangioma and 1 of cholangiocellular carcinoma. In addition, several non-hepatic tumours were found in the vicinity of these liver neoplasms, representing exocrine pancreatic adenoma (Fourne et al. 1988), hemangioendothelioma, and adenocarcinoma possibly of renal origin. The pattern of occurrence of carcinoma reflected that of hepatıc adenoma (Table 3), with highest prevalences at coastal sites (Sites 6 and 7) and in the spawning area (S).

- The remaining $32.9 \%$ of liver nodules included foci of cellular alteration $(26.7 \%)$, while the remaining

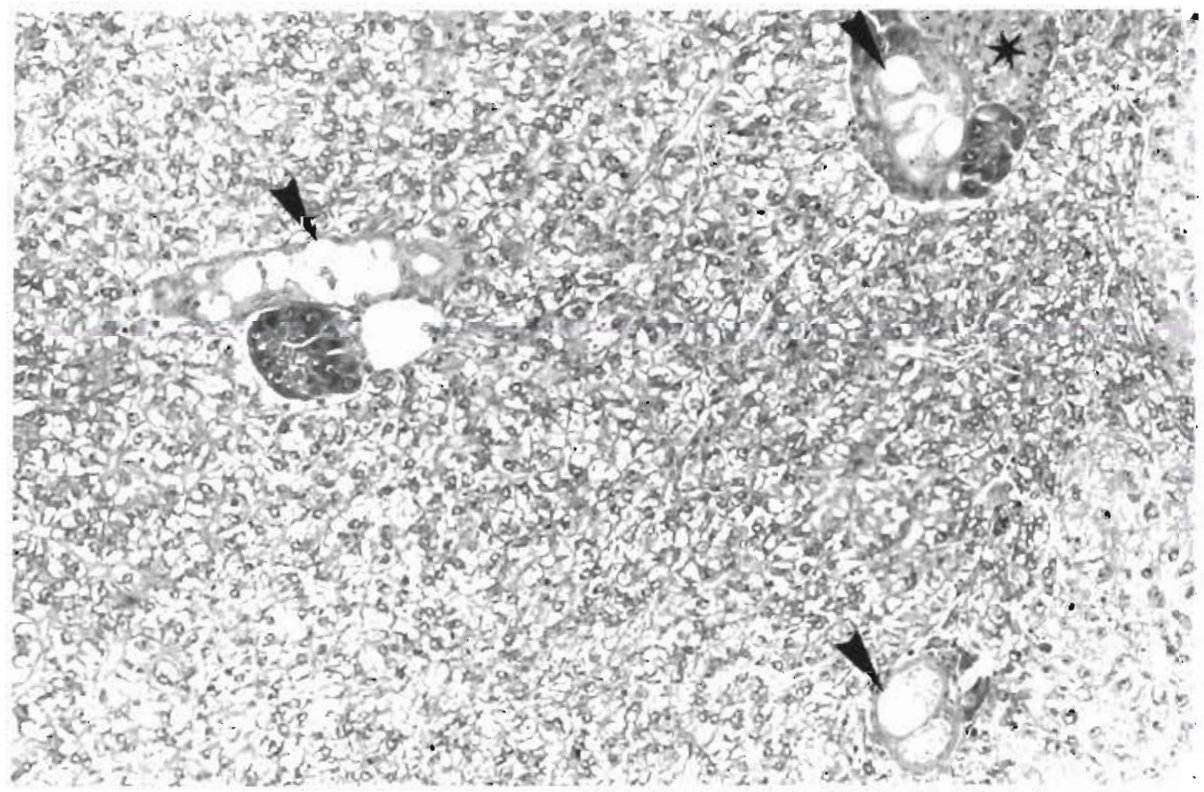

Fig. 10. Platichthys flesus, Liver with hydropic vacuolization of biliary epithelial cells. Note extreme swelling of bile duct epithelium (large arrowheads); also melanomacrophage centre (asterisk) and on the right a small rim of adjacent hepatocellular carcinoma. $\mathrm{H} \& \mathrm{E}, \times 160$ 
Table 2. Platichthys flesus. Criteria used to distinguish the various types of 'vacuolated' lesions

\begin{tabular}{|llll|}
\hline Feature & $\begin{array}{l}\text { Hydropic vacuolization } \\
\text { of biliary epithelial cells }\end{array}$ & $\begin{array}{l}\text { Focal hepatocellular } \\
\text { vacuolization }\end{array}$ & $\begin{array}{l}\text { Foci of cellular } \\
\text { alteration }\end{array}$ \\
\hline $\begin{array}{lll}\text { Distribution } \\
\text { Fibrous sheath }\end{array}$ & In bile tracts & Throughout the liver & Throughout the liver \\
Compression & Present & Absent & Absent \\
Relation to diffuse hepatic vacuolization & Absent & Andependent & Dependent \\
Translucent cytoplasm & Well defined/circular & Irregular & Independent \\
Nuclear morphology & Compression & Compression/pyknosis & Normal \\
\hline
\end{tabular}

Table 3. Platichthys flesus. Number of fish examined for gross liver abnormalities at each site, number with nodules, and number subsequently confirmed as having hepatic neoplasms. Prevalences (\%) are given in italics. Range of fish lengths $20-45 \mathrm{~cm}$

\begin{tabular}{|c|c|c|c|c|c|c|c|c|c|c|c|}
\hline \multirow{2}{*}{$\begin{array}{l}\text { Season } \\
\text { Late summer }\end{array}$} & \multirow{2}{*}{$\begin{array}{l}\text { Site } \\
\\
1\end{array}$} & \multirow{2}{*}{$\begin{array}{c}\text { Year } \\
1987-89\end{array}$} & \multirow{2}{*}{$\begin{array}{c}\text { Fish } \\
\text { examined } \\
1160\end{array}$} & \multicolumn{2}{|c|}{$\begin{array}{c}\text { Fish with gross } \\
\text { liver lesions } \\
\text { (nodules) }\end{array}$} & \multicolumn{2}{|c|}{$\begin{array}{l}\text { Fish with con- } \\
\text { firmed hepatic } \\
\text { adenoma }^{\text {a }}\end{array}$} & \multicolumn{2}{|c|}{$\begin{array}{l}\text { Fish with con- } \\
\text { firmed hepatic } \\
\text { carcinoma }\end{array}$} & \multicolumn{2}{|c|}{$\begin{array}{l}\text { Total fish with } \\
\text { confirmed liver } \\
\text { neoplasms }\end{array}$} \\
\hline & & & & 0 & 0.0 & 0 & 0.0 & 0 & 0.0 & 0 & 0.0 \\
\hline & 2 & $1987-89$ & 1368 & 1 & 0.1 & 1 & 0.1 & 0 & 0.0 & 1 & 0.1 \\
\hline & 3 & $1987-89$ & 818 & 15 & 1.8 & 10 & 1.2 & 1 & 0.1 & 11 & 1.3 \\
\hline & 4 & $1985-89$ & 2363 & 5 & 0.2 & 2 & 0.1 & 0 & 0.0 & 2 & 0.1 \\
\hline & 5 & $1985-89$ & 2385 & 30 & 1.3 & 16 & 0.7 & 4 & 0.4 & 20 & 0.8 \\
\hline & 6 & $1985-89$ & 1436 & 44 & 3.1 & 23 & 1.6 & 4 & 0.2 & 27 & 1.9 \\
\hline & 7 & $1987-89$ & 1269 & 68 & 5.4 & 36 & 2.8 & 7 & 0.6 & 43 & 3.4 \\
\hline & 8 & $1987-89$ & 1054 & 7 & 0.7 & 3 & 0.3 & 0 & 0.0 & 3 & 0.3 \\
\hline & 9 & $1987-89$ & 817 & 0 & 0.0 & 0 & 0.0 & 0 & 0.0 & 0 & 0.0 \\
\hline & \multicolumn{2}{|l|}{ Total } & 12670 & 170 & 1.3 & 91 & 0.7 & 16 & 0.1 & 107 & 0.8 \\
\hline Late winter & $\mathrm{S}$ & 1988 & 1856 & 40 & 2.2 & 30 & 1.7 & 4 & 0.2 & 34 & 1.8 \\
\hline All sites + seasons & $1-9+S$ & $1985-88$ & 14526 & 210 & 1.4 & 121 & 0.8 & 20 & 0.1 & 141 & 1.0 \\
\hline
\end{tabular}

Fig. 11 Platichthys flesus. Multifocal hepatocellular hypervacuolization (arrowheads). Note absence of fibrous sheath, irregular shape, slight compression, and condensed nuclei. $H \& E, \times 160$

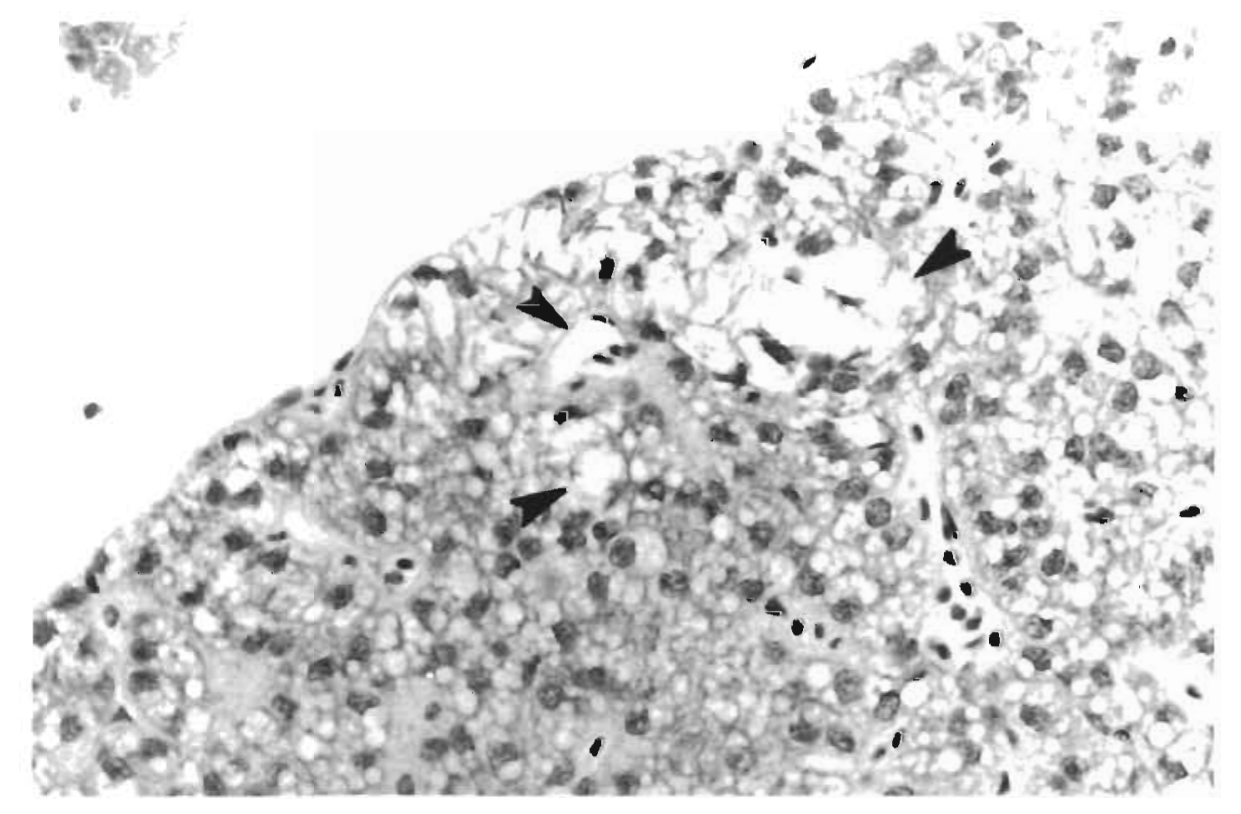




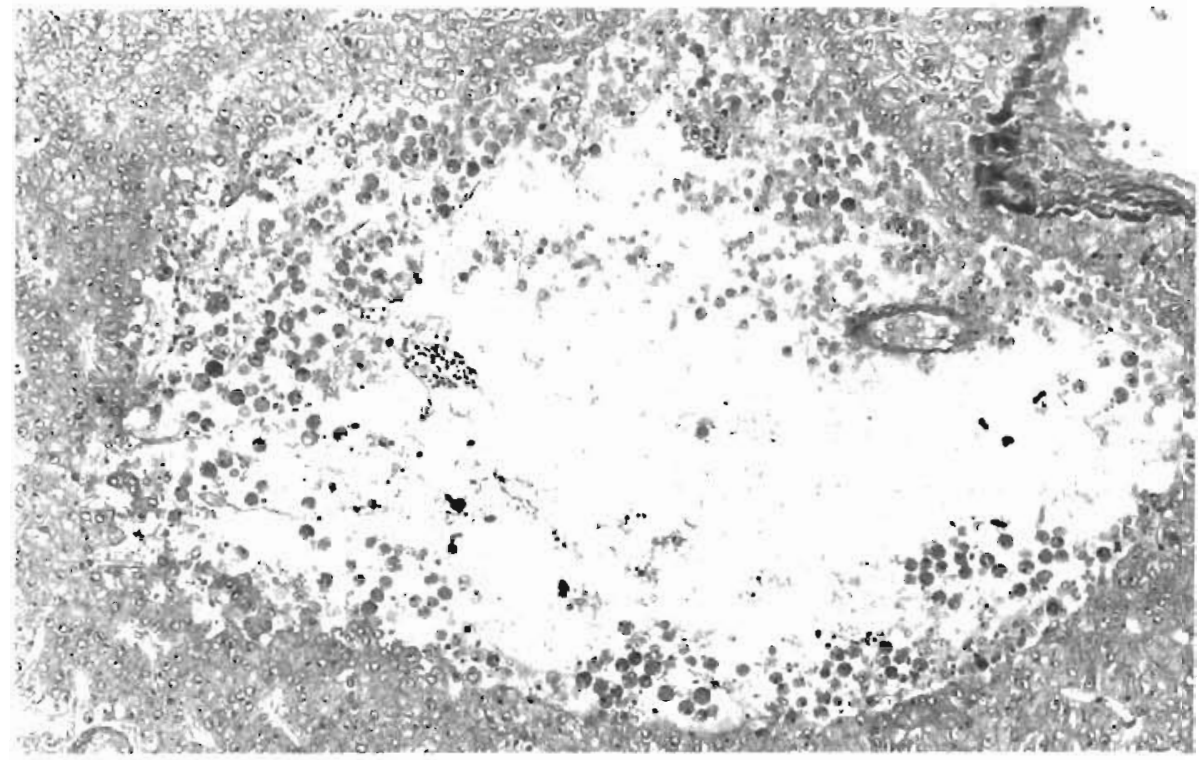

Fing 12. Platichthys flesus Iiver with focal necrosis. Presence of tissue response established by peripheral invasion of macrophages. H\&E, $\times 160$

nodules $(62 \%$ of nodules) were diagnosed as hemangloma, parasitic lesions with chronic inflammatory tissue, or cysts.

- The probability that a grossly observed nodule corresponded to a neoplasm increased with the diameter of the nodule: over $90 \%$ of nodules greater than $10 \mathrm{~mm}$ in diameter appeared to be neoplastic, whereas half of those between 2 and $5 \mathrm{~mm}$ in diameter were diagnosed as foc or areas of cellular alteration (Fig 15)

- The mean diameter of observed nodules showed no clear spatial or seasonal trend. However, the diameter of the largest nodules detected in individual fish increased with age, indicating a progression of these lesions during the lifetime of the fish (Fig 16)

\section{Histological investigation of livers without nodules}

The prevalences of histologically observed lesions in livers without gross nodules at the different sites are presented in Table 4 . Overall, the 2 most prevalent types of lesion-each occurring in over $11 \%$ of the livers examined-were focj of cellular alteration and inflammatory lesions, the latter including both lesions of parasitic origin and hepatitis. Two other conditions were detected in more than $5 \%$ of the fish, namely focal necrosis and regenerative foci

In terms of spatial distribution, the occurrence of hepatocellular adenoma was confined to 1 liver at Site 5 and that of foci of cellular alteration was restricted to sites of high salinity (Sites 3 to 8). Hydro-

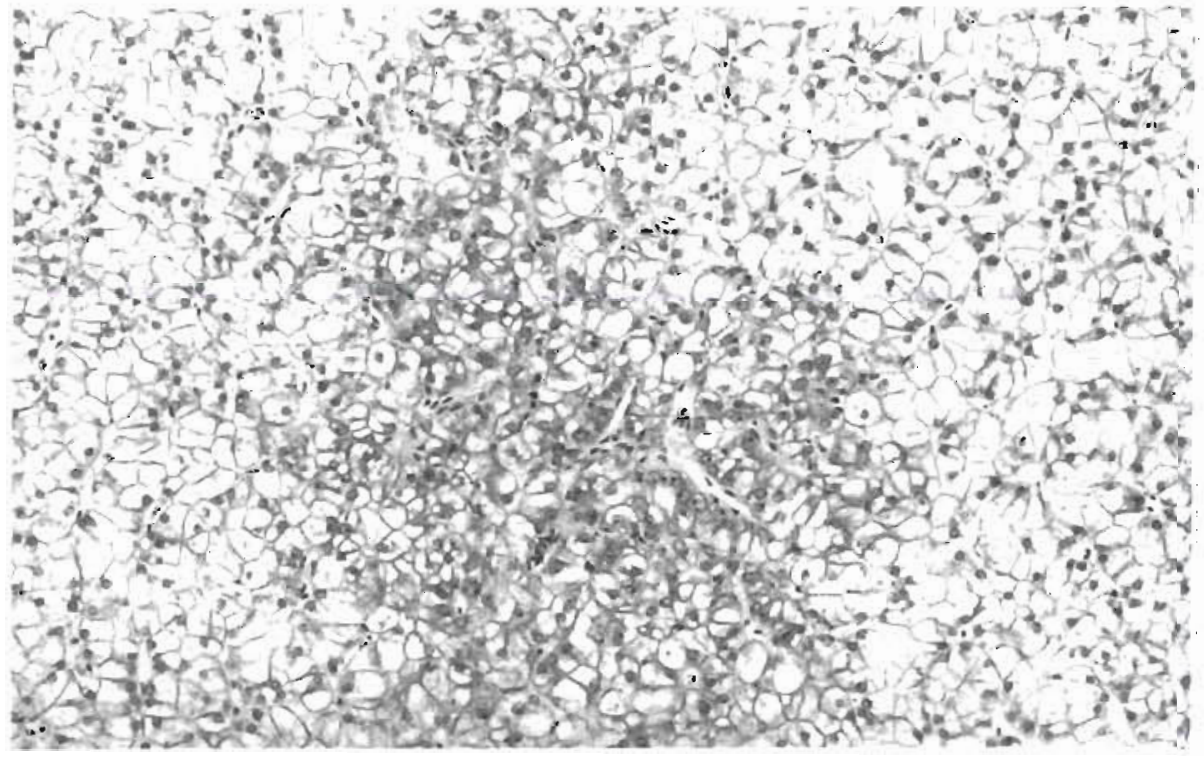

Fig. 13. Platichthys flesus, Liver with regenerative focus. $H \& E$, $\times 180$ 
Fig. 14. Platichthys flesus. Liver showing hepatocytes with fibrillar cytoplasm (arrowheads). H\&E, $\times 800$

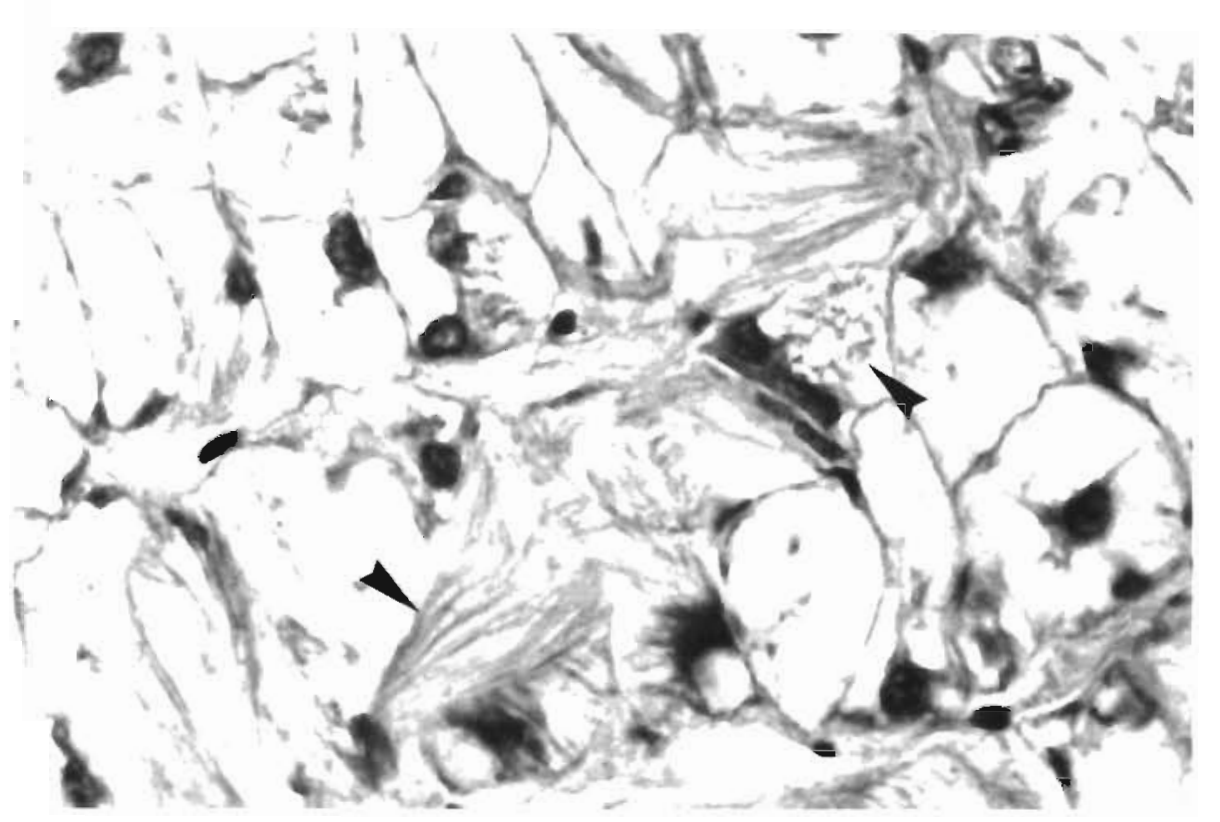

pic vacuolization of biliary epithelial cells, hepatocellular hypervacuolization and fibrillar hepatocytes ( $1 \%$ of livers from Site 7 and Area S) were also confined to the sites of high salinity, while inflammatory lesions and focal necrosis were more evenly distributed over the whole study area (Table 3).

A seasonal comparison (late summer 1987 versus late winter 1988) revealed higher prevalences of most types of lesion, notably inflammatory lesions, focal necrosis and particularly regenerative foci, in flounder captured in Area S (spawning area) during late winter. The relatively high prevalence of foci of cellular alteration coincided with the high prevalences of liver neoplasms observed during this period (Table 3).

There appeared to be a clear positive correlation between the prevalence of foci of cellular alteration and age. There was a general but less clear trend of increasing prevalence with age for hydropic vacuoli-

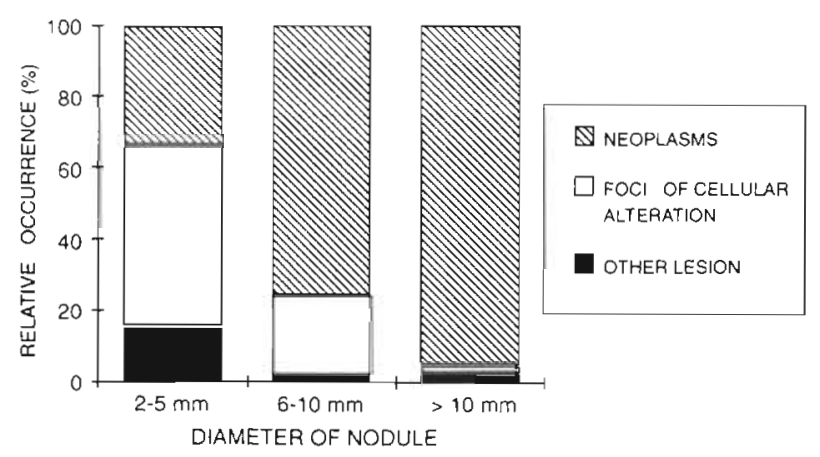

Fig. 15. Platichthys flesus. Histological characterization of different sizes of liver nodules observed during gross inspection ( $n=210 ;$ see Table 2 ) zation of biliary epithelial cells, but the same did not apply to the other types of lesions (Fig. 17). Male and female flounder showed only minor differences in the prevalences of the various types of lesion.

Using the index formulated (see 'Materials and methods: Histological techniques'), there appeared to be no relationship between the extent of hepatic storage vacuolization and the age of the fish (Fig. 18). The spatial pattern of vacuolization (Fig. 19) did not correspond with that observed for foci of cellular alteration (Table 3). However, there was a clear seasonal trend with reduced storage in late winter (Area S) as compared to late summer, indicating poor condition of the fish during or after spawning (Fig. 19).

The density of MMCs, as evaluated by the index, was positively related to the age of the fish (Fig. 20). The density of MMCs at the different sampling sites is shown in Fig. 21. However, the values in this figure

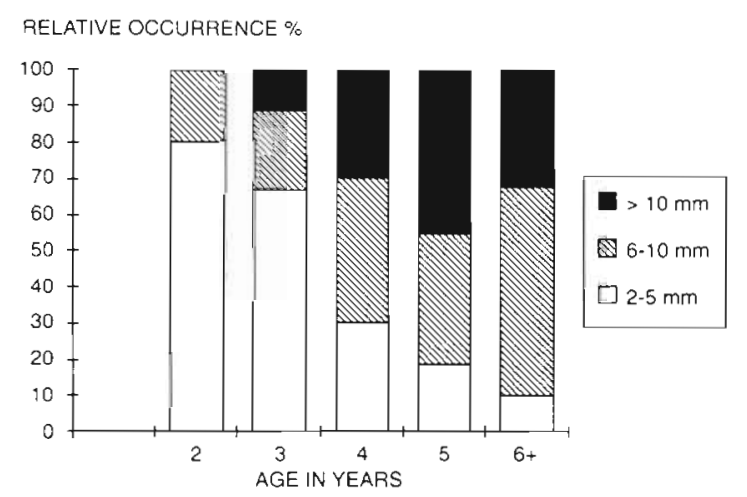

Fig. 16. Platichthys flesus. Diameter of liver nodules subsequently confirmed to be neoplasms, in relation to the age of the fish ( $n=141$; see Table 2) 
Table 4. Platichthys flesus. Summary of findings of routine histopathology: number of normal livers and of livers showing 7 different types of lesion, with prevalence $(\%)$ in italics

\begin{tabular}{|c|c|c|c|c|c|c|c|c|c|c|c|c|c|c|c|c|c|}
\hline \multirow{2}{*}{$\begin{array}{l}\text { Season } \\
\text { Late summer }\end{array}$} & \multirow{2}{*}{$\begin{array}{c}\text { Site } \\
\\
1\end{array}$} & \multirow{2}{*}{$\begin{array}{c}\text { Number } \\
\text { examined } \\
\\
\\
35\end{array}$} & \multirow{2}{*}{$\begin{array}{c}\begin{array}{c}\text { Within } \\
\text { normal } \\
\text { limits }\end{array} \\
33\end{array}$} & \multicolumn{2}{|c|}{$\begin{array}{l}\text { Hepato- } \\
\text { cellular } \\
\text { adenoma }\end{array}$} & \multicolumn{2}{|c|}{$\begin{array}{l}\text { Foci of } \\
\text { cellular } \\
\text { alteration }\end{array}$} & \multicolumn{2}{|c|}{$\begin{array}{l}\text { Hydropic } \\
\text { vacuolization } \\
\text { of biliary epi- } \\
\text { thelial cells }\end{array}$} & \multicolumn{2}{|c|}{$\begin{array}{c}\text { Focal hepato- } \\
\text { cellular } \\
\text { hypervacu- } \\
\text { olization }\end{array}$} & \multicolumn{2}{|c|}{$\begin{array}{l}\text { Inflam- } \\
\text { matory } \\
\text { lesions }\end{array}$} & \multicolumn{2}{|c|}{$\begin{array}{c}\text { Focal } \\
\text { necrosis }\end{array}$} & \multicolumn{2}{|c|}{$\begin{array}{l}\text { Regen- } \\
\text { erative } \\
\text { foci }\end{array}$} \\
\hline & & & & 0 & 0.0 & 0 & 0.0 & 0 & 0.0 & 0 & 0.0 & 2 & 5.7 & 0 & 0.0 & 0 & 0.0 \\
\hline & 2 & 35 & 33 & 0 & 0.0 & 0 & 0.0 & 0 & 0.0 & 0 & 0.0 & 1 & 2.9 & 1 & 2.9 & 0 & 0.0 \\
\hline & 3 & 25 & 17 & 0 & 0.0 & 3 & 12.0 & 3 & 12.0 & 1 & 4.0 & 4 & 16.0 & 2 & 8.0 & 0 & 0.0 \\
\hline & 4 & 35 & 30 & 0 & 0.0 & 1 & 2.9 & 1 & 2.9 & 0 & 0.0 & 1 & 2.9 & 1 & 2.9 & 1 & 2.9 \\
\hline & 5 & 35 & 26 & 0 & 0.0 & 4 & 16.0 & 1 & 2.9 & 0 & 0.0 & 5 & 14.3 & 1 & 2.9 & 0 & 0.0 \\
\hline & 6 & 25 & 15 & 0 & 0.0 & 7 & 28.0 & 2 & 8.0 & 0 & 0.0 & 2 & 8.0 & 2 & 8.0 & 2 & 2.9 \\
\hline & 7 & 35 & 23 & 1 & 2.9 & 7 & 20.0 & 1 & 2.9 & 1 & 2.9 & 5 & 14.3 & 2 & 5.7 & 0 & 0.0 \\
\hline & 8 & 35 & 28 & 0 & 0.0 & 4 & 11.4 & 1 & 2.9 & 1 & 2.9 & 4 & 11.4 & 1 & 2.9 & 0 & 0.0 \\
\hline & 9 & 20 & 18 & 0 & 0.0 & 0 & 0.0 & 0 & 0.0 & 0 & 0.0 & 2 & 10.0 & 0 & 0.0 & 0 & 0.0 \\
\hline & Total & 280 & 223 & 2 & 0.7 & 26 & 9.3 & 9 & 3.2 & 3 & 1.1 & 26 & 9.3 & 10 & 3.6 & 3 & 1.1 \\
\hline Late winter & $\mathrm{S}$ & 35 & 26 & 0 & 0.0 & 10 & 28.6 & 2 & 5.7 & 2 & 5.7 & 11 & 31.4 & 7 & 20.0 & 14 & 40.0 \\
\hline All sites + seasons & $1-9+S$ & 315 & 249 & 1 & 0.3 & 36 & 11.4 & 11 & 3.5 & 5 & 1.8 & 37 & 11.7 & 17 & 5.4 & 17 & 5.4 \\
\hline
\end{tabular}

are not adjusted for age-related effects, such as differences in growth rates among sampling sites. Comparisons involving similar age groups revealed no clear spatial trends, but showed a clearly higher density of MMCs in late winter (Area S) than in late summer, again possibly associated with poor condition and spawning stress. In addition, the average size of the MMCs appeared to be smaller during late winter.

Histological investigation showed that 66 out of 315 livers lacking gross nodules $(21 \%)$ nevertheless bore 1 or more lesions of the types listed in Table 4. Many of these livers bore lesions of more than 1 type (Table 5). There was a positive association between the following pairs of frequently occurring lesions: foci of cellular alteration and hydropic vacuolization of biliary epithelial cells; foci of cellular alteration and regenerative foci; inflammatory lesions and focal necrosis; focal necrosis and regenerative lesions (Table 5).

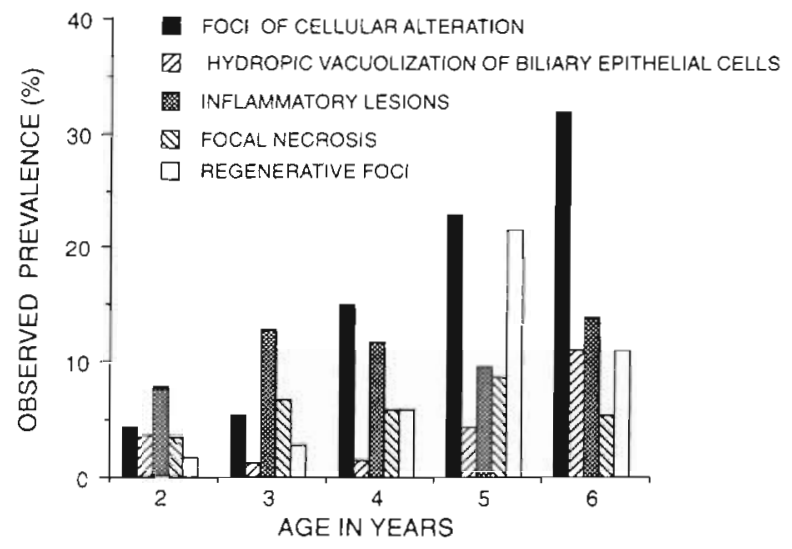

Fig. 17. Platichthys flesus. Prevalence of frequently occurring types of liver lesion in relation to age of the fish (livers without nodules, total no. examined $=315$, see Table 3 )
The estimated odds ratios (with $95 \%$ confidence intervals) for the effects of site and length group on the occurrence of foci of cellular alteration and inflammatory lesions are given in Table 6. For both types of lesions, there were significant differences among sites, but 2 -way interactions between site and length were not significant. Large flounder were more likely to have foci of cellular alteration than small ones, but the effect of length was not significant for inflammatory lesions.

For foci of cellular alteration, estimated odds ratios were significantly greater than 1 at the coastal sites (Sites 6 and 7) and in the Wadden Sea (Site 8). Estimated odds ratios were greater than 1 (but not significantly) at all other coastal sites. The disease was absent from low-salinity sites (Sites 1, 2 and 9) (Table 6). Estimated odds ratios for inflammatory lesions were significantly greater than 1 at most coastal sites (Sites 3, 5 and 7). The estimated odds ratios for all other sites including those of low salinity were greater than (but not significantly) or equaled the value of 1 (Table 6).

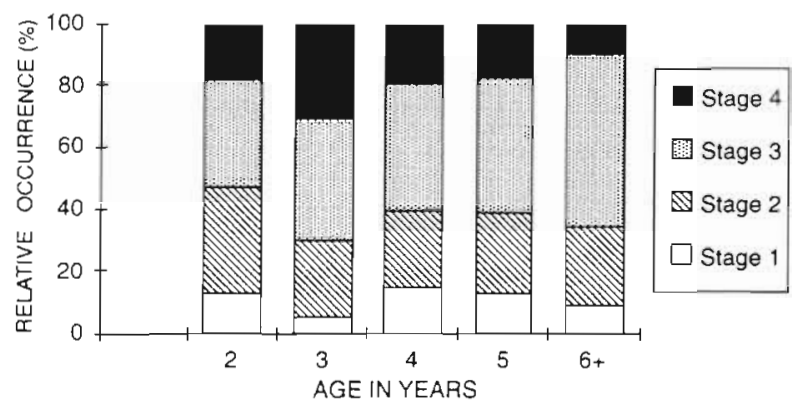

Fig. 18. Platichthys flesus. Extent of hepatic storage vacuolization in relation to age of the fish (livers without nodules, total no. examined $=315$; see Table 1 ). See text for details of index used to describe the extent of vacuolization 


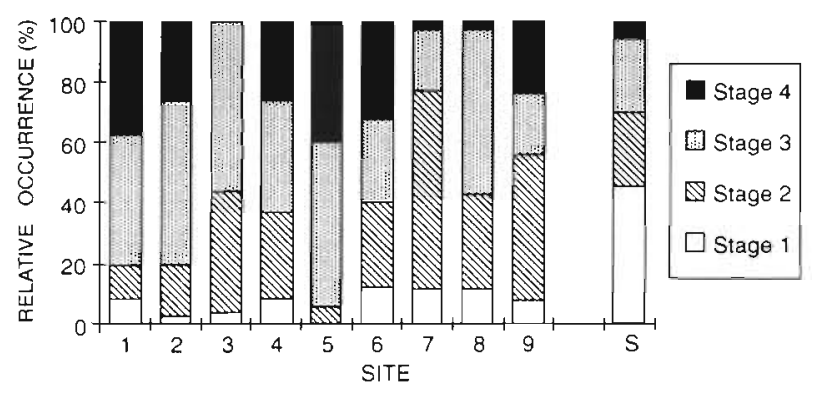

Fig. 19. Platichthys flesus. Extent of hepatic storage vacuolization in fish from each sampling site (livers without nodules, total no. examined $=315$; see Table 1 )

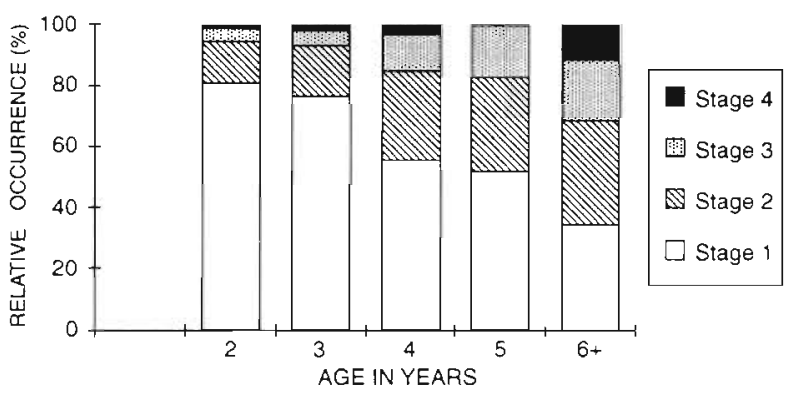

Fig. 20. Platichthys flesus. Density of hepatic MMCs in relation to age of the fish (livers without nodules, total no. examined $=315$; see Table 1); see text for details of index used to describe MMC occurrence

The prevalence of foci of cellular alteration (Table 6) corresponded very well to the pattern of occurrence of neoplastic nodules in the same fish populations (Vethaak \& Jol 1996; Fig. 1), but not to that of inflammatory lesions (Table 6). Using (log) disease odds, the correlation coefficients between the prevalence of these neoplastic nodules and the prevalence of foci of

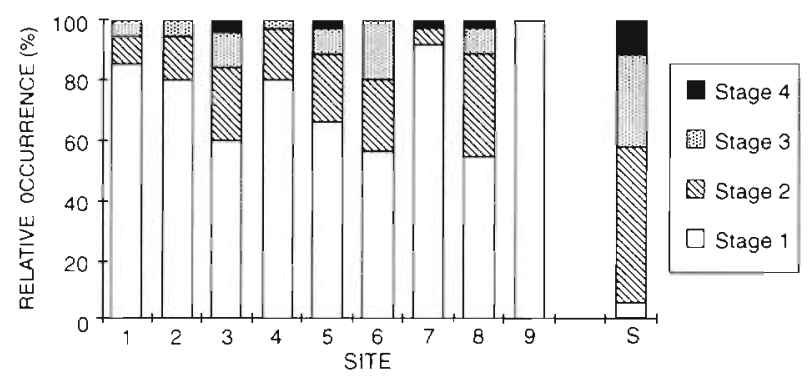

Fig. 21. Platichthys flesus. Density of hepatic MMCs in fish from each sampling site (livers without nodules, total no. examined $=315$; see Table 1 ); values are not adjusted for the effect of age

cellular alteration was $\mathrm{r}=+0.99 ; \mathrm{p}<0.001$. For neoplastic nodules and inflammatory lesions the correlation coefficient was $r=+0.51 ; \mathrm{p}=0.15$.

Taking into account all sampling sites, correlations between the occurrence of foci of cellular alteration and levels of PCB-153, or for $\mathrm{Cd}$ in the liver were negative. Furthermore, no significant correlation existed between the occurrence of this lesion type and the concentrations of PCB-153, PAHs [sum of benz(b)fluoranthene, benz(k)fluoranthene and benz(a)pyrene], $\mathrm{Cd}$ or $\mathrm{Pb}$ in the sediment. The corresponding correlations for inflammatory lesions were also nonsignificant, with the exception of liver $\mathrm{Cd}$ concentration $(\mathrm{r}=-0.824 ; \mathrm{p}<0.01)$

\section{DISCUSSION}

The occurrence of neoplastic and putative preneoplastic liver lesions in fish populations has received much attention of late. The development of these lesions is slow but the end products (tumours) are

Table 5. Platichthys flesus. Contingency table showing association between frequently occurring types of lesions (FCA $=$ foci of cellular alteration; HVB = hydropic vacuolization of biliary epithelial cells; INF = inflammatory lesions; FNE = focal necrosis; $\mathrm{RGF}=$ regenerative foci). Cells on the lower left show numbers of livers with different combinations of 2 diseases $(+=$ diseased fish $_{j}-=$ apparently non-diseased fish). Cells on the upper right show associated probabilities derived from Yates' corrected chi-squared test

\begin{tabular}{|c|c|c|c|c|c|c|c|c|c|c|}
\hline & FCA. & FCA- & HVB & HVB- & INF & INF- & FNE & FNE- & RGF & RGF- \\
\hline $\begin{array}{l}\text { FCA+ } \\
\text { FCA- }\end{array}$ & $\begin{array}{l}36 \\
-\end{array}$ & $\begin{array}{r}- \\
279\end{array}$ & \multicolumn{2}{|c|}{$p=0.002$} & \multicolumn{2}{|c|}{$p=0.881$} & \multicolumn{2}{|c|}{$p=0.662$} & \multicolumn{2}{|c|}{$p=0.001$} \\
\hline $\begin{array}{l}\text { HVB+ } \\
\text { HVB- }\end{array}$ & $\begin{array}{l}5 \\
31\end{array}$ & $\begin{array}{r}6 \\
273\end{array}$ & $\begin{array}{l}11 \\
-\end{array}$ & $\begin{array}{r}- \\
304\end{array}$ & \multicolumn{2}{|c|}{$p=0.250$} & \multicolumn{2}{|c|}{$\mathrm{p}=1.0$} & \multicolumn{2}{|c|}{$p=1.0$} \\
\hline $\begin{array}{l}\text { INF+ } \\
\text { INF- }\end{array}$ & $\begin{array}{l}5 \\
31\end{array}$ & $\begin{array}{r}32 \\
247\end{array}$ & $\begin{array}{l}3 \\
8\end{array}$ & $\begin{array}{r}34 \\
270\end{array}$ & $\begin{array}{l}37 \\
-\end{array}$ & $\begin{array}{r}- \\
278\end{array}$ & \multicolumn{2}{|c|}{$p=0.001$} & \multicolumn{2}{|c|}{$p=0.053$} \\
\hline $\begin{array}{l}\text { FNE+ } \\
\text { FNE- }\end{array}$ & $\begin{array}{l}3 \\
33 \\
\end{array}$ & $\begin{array}{r}14 \\
265 \\
\end{array}$ & $\begin{array}{l}1 \\
10\end{array}$ & $\begin{array}{r}16 \\
288\end{array}$ & $\begin{array}{l}7 \\
30\end{array}$ & $\begin{array}{r}10 \\
266\end{array}$ & $\begin{array}{l}17 \\
-\end{array}$ & $\begin{array}{r}- \\
298\end{array}$ & \multicolumn{2}{|c|}{$p=0.001$} \\
\hline $\begin{array}{l}\text { RGF+ } \\
\text { RGF- }\end{array}$ & $\begin{array}{l}7 \\
29\end{array}$ & $\begin{array}{r}10 \\
269\end{array}$ & $\begin{array}{l}1 \\
10\end{array}$ & $\begin{array}{r}16 \\
288\end{array}$ & $\begin{array}{l}5 \\
32\end{array}$ & $\begin{array}{r}12 \\
266\end{array}$ & $\begin{array}{l}5 \\
12\end{array}$ & $\begin{array}{r}12 \\
286\end{array}$ & $\begin{array}{l}17 \\
-\end{array}$ & $29 \overline{-}$ \\
\hline
\end{tabular}


Table 6. Platichthys flesus. Estimated odds ratios (with $95 \%$ confidence intervals) for effects of site and length on the occurrence of foci of cellular alteration (FCA) and inflammatory lesions (INF), adjusted for the effects of length and site respectively

\begin{tabular}{|ccccc|}
\hline Effect & Relative to & \multicolumn{2}{c}{ FCA } & \multicolumn{1}{c|}{ INF } \\
\hline Site 1 & Site 4 & $0.0(0.0-0.0)$ & $2.1(0.3-24.7)$ \\
Site 2 & Site 4 & $0.0(0.0-0.0)$ & $1.0(0.1-17.6)$ \\
Site 3 & Site 4 & $4.2(0.8-45.6)$ & $6.5(1.3-64.8)$ \\
Site 5 & Site 4 & $4.4(0.9-44.2)$ & $5.6(1.2-53.3)$ \\
Site 6 & Site 4 & $12.2(2.6-96.5)$ & $2.9(0.5-36.3)$ \\
Site 7 & Site 4 & $8.6(1.8-77.0)$ & $5.7(1.2-53.6)$ \\
Site 8 & Site 4 & $5.7(1.2-53.5)$ & $4.4(0.9-43.3)$ \\
Site 9 & Site 4 & $0.0(0.0-0.0)$ & $3.8(0.6-46.8)$ \\
Large & Small & $2.1(1.1-4.0)$ & & - \\
\hline
\end{tabular}

irreversible, therefore they are potentially suitable for monitoring long-term cumulative effects of environmental disturbance, especially pollution.

Recently, several European researchers have described the occurrence of hepatocellular abnormalities in 2 species of flatfish, dab Limanda limanda and flounder, and have discussed the possible association between these changes and the presence of chemical contaminants in the North Sea Bucke \& Watermann 1988, Köhler 1989, Moore 1992, Vethaak 1992b, Vethaak \& ap Rheinallt 1992, Vethaak et al. 1992, Bucke \& Feist 1993). Similar liver abnormalities have been described in other flatfish species from polluted North American waters, and convincing evidence has been provided to implicate PAHs as an important causal agent (Malins et al. 1988, Vogelbein et al. 1990, Myers et al. 1991, 1994)

However, Vethaak \& Jol (1996) found that the spatial pattern of liver nodules corresponding to neoplasms did not suggest a straightforward relationship with pollution. This conclusion is not affected by the results of the more detailed histopathological analysis reported here: the spatial and seasonal pattern of putative preneoplastic lesions was similar to that of grossly visible nodules and of histologically confirmed neoplasms. Prevalences of putative preneoplastic lesions were highest in coastal waters (Sites 3, 5, 6 and 7), lower at the reference site (Site 4) and in the Wadden Sea (Site 8), and virtually nil at the estuarine sites (Sites 1,2 and 9)

The correspondence between foci of cellular alteration and tumours, in terms of spatial trends and of agerelated variation in prevalence, supports the possibility of a progression from the former towards the latter (Hinton 1989, Myers et al. 1991, Schiewe et al. 1991).

The spatial distribution of hydropic vacuolization of biliary epithelial cells showed similarities to the distribution of neoplasms, while there was also an association, in individual fish, with the occurrence of foci of cellular alteration. Similar lesions have recently been reported to occur in biliary epithelial cells or hepato- cytes of winter flounder (Bodammer \& Murchelano 1990) and white perch Morone americana (Camus \& Wolke 1991) from North American waters. These authors, who suggested a relationship with environ. mental degradation for these lesions, considered the cells to be hepatocytes, although in our material the condition seemed to be limited to bile duct epithelium, as was reported and discussed by Moore et al. (1989) for winter flounder and Stehr et al. (1991) for rock sole Lepidopsetta bilineata and starry flounder Platichthys stellatus. Several authors have documented the association of this lesion with contaminant exposure in several species (Johnson et al. 1993, Myers et al. 1994), and it is generally considered a convenient histological biomarker of contaminant exposure. Although we did find tocal hypervacuolated hepatocytes which were nui associated with the bile ducts, they showed different characteristics (Table 2) from the bile duct lesion, and were therefore classified separately.

The spatial distribution of MMCs and hepatic storage products did not suggest any link with pollution, but the presence of seasonal variation indicated a relationship with nutritional condition.

It was not possible to simultaneously account for fish age or sex in the analysis of lesion odds versus contaminant parameters in liver and sediment due to insufficient numbers of diseased fish. Instead length was taken as a measure of age and the sex was ignored. Although the absence of liver neoplasms in flounder from highly contaminated freshwater and brackish-water sites (especially Sites 1 and 2) may be partially explained by the fact that these polluted sites are inhabited predominantly by young fish (2 to $3 \mathrm{yr}$ old), the absence of putative preneoplastic lesions and hydropic vacuolization of biliary epithelial cells in livers from the same sites indicates that factors other than pollutants may be involved in the development of these diseases. It is clear from this study that the migratory behaviour of the flounder should be explicitly taken into account in any assessment of pollutants. Detrimental toxic or carcinogenic effects produced by exposure at any stage during the life of the individual as well as other environmental and hostrelated factors should be considered.

In classical human diagnostic pathology, much effort is given to the classification of neoplastic changes. This classification reflects the biological behaviour of the lesions, in particular their potential lethality through invasion and metastasis. However, very little is known about the biological behaviour of neoplasms in wild fish, and about the subsequent fate of the fish. Nevertheless, in common with other authors we have used the terms adenoma and carcinoma in this study, based on the histological and cytological appearance of the observed lesions. 
The characteristics of these lesions and their presumed precursors in flounder correspond fairly well to those recorded in American flatfish species (Myers et al. 1987, Malins et al. 1988, Moore et al. 1989, Murchelano \& Wolke 1991), and form a continuum ranging from foci of cellular alteration to hepatocellular adenoma and occasionally hepatocellular carcinoma

However, nuclear pleomorphism and megalocytic hepatosis, as described by Myers et al. (1987) in English sole, were not observed; these toxicopathic lesions may be species-specific or short-lived. Also, we did not include hepatic steatosis as a distinct category since it is difficult to distinguish this from clear-cell foci (or areas), and its degenerative nature is difficult to establish, as is the hyperplastic nature of the foci.

Some livers showed symptoms suggestive of widespread single-cell degeneration and possibly apoptosis, as occasionally reported in the literature (Köhler 1989). However, we did not consider the paraffin-embedded field samples suitable for a decisive diagnosis of such subtle change.

Another interesting finding was the occurrence of cytoplasmic fibrils oriented as parallel or converging basophilic stacks. Using light microscopy, the resulting structures resembled the fibrillar hepatocytes described by Stehr et al. (1988) in hepatocellular carcinomas of English sole. A similar finding was reported by Köhler (1989) in non-tumourous liver in European flounder. These authors identified the fibrils as dilated rough endoplasmic reticulum (RER) containing microfilamentous material. Unlike Stehr et al. (1988), however, we found these structures exclusively in nontumorous cells, even in the case of one liver which contained a carcinoma.

The prevalence data in Table 3 show that in a wideranging epizootiological study, gross lesions can be used as reliable indicators of histological changes. Recording distinct nodules, with a diameter exceeding $2 \mathrm{~mm}$, ensures that the majority of neoplasms are detected. Nevertheless, some neoplasms are missed by this approach (Table 3), resulting in an underestimate of true prevalence. In fact, even routine histopathological investigation of unaffected livers as in the present study does not guarantee that all cases of neoplasms are detected, because only a single section per liver is routinely examined.

Table 3 shows that $1.4 \%$ of all fish examined had nodules but only $1 \%$ of them had confirmed neoplasms. Clearly, histological confirmation of observed nodules is very important, since a proportion of nodules $(33 \%$ in the present study) are not neoplasms. In the case of older fish (aged 6+yr), however, the occurrence of large nodules (diameter $>10 \mathrm{~mm}$ ) appears to be an accurate useful predictor of neoplasms by itself (Fig. 15), even without histological confirmation.
Though useful in the detection of additional cases of neoplasms, routine histology is particularly advisable as a method of detecting preneoplastic and other associated lesions which may occur at higher prevalences and in younger fish than do neoplasms.

\section{CONCLUSIONS}

This study demonstrates that a wide-ranging epizootiological survey, relying largely on recording gross liver anomalies, is a cost-effective method of collecting data on the occurrence of liver neoplasms in flounder. However, reasonable accuracy in the diagnosis of neoplasms can only be ensured by histological analysis.

Detailed histological investigation of flounder livers revealed a large array of lesions, of which foci of cellular alteration (putative preneoplastic lesions) and hydropic vacuolization of biliary epithelial cells were the most significant.

The spatial and seasonal patterns of occurrence of putative preneoplastic lesions recorded during routine histological investigation of apparently healthy livers showed a good correspondence with the patterns of occurrence of grossly detected liver neoplasms. However, the histological investigation did not provide further insights into the nature of any possible relationship with pollution. Livers of flounder sampled in highly contaminated freshwater and brackish-water sites did not show any signs of neoplasia, indicating that factors other than pollutants may be involved in the complex process of hepatocarcinogenesis.

The only other type of lesion showing a similar spatial patterns to neoplastic and putative preneoplastic lesions was hydropic vacuolization of biliary epithelial cells.

The findings indicate that the occurrence of liver neoplasms in flounder could well provide a suitable tool for monitoring exposure to potential carcinogens. However, the use of these lesions in pollution monitoring studies will require further research into the migratory behaviour of the indicator species. Because of the long latency period associated with tumour development and the low observed prevalences, there is a need to identify, and to utilize wherever possible, histological markers that precede tumour formation and occur at higher prevalences. Good candidates, as indicated by this study, are foci of cellular alteration and hydropic vacuolization of biliary epithelial cells. Finally, experimental studies are needed to investigate the chemical agents responsible for the onset of these early lesions and their progression into neoplasms, and to evaluate the contribution of other environmental and host-related factors. 
Acknowledgements. We thank Joke Robinson, Jan Hoekman and Henny Hoendersloot for their assistance with the histological work. We also thank 2 anonymous reviewers for useful suggestions and comments on the manuscript.

\section{LJTERATURE CITED}

Agius C, Agbede SA (1984) An electron microscopical study on the genesis of lipofuscin, melanin and haemosiderin in the haemopoietic tissues of fish. J Fish Biol 24:471-488

Bodammer JE, Murchelano RA (1990) Cytological study of vacuolated cells and other aberrant hepatocytes in winter flounder from Boston harbour. Cancer Res 50 $6744-6756$

Bucke D, Feist SW (1993) Histopathological changes in the livers of dab (Limanda limanda L.). J Fish Dis 16:281-296

Bucke D, Watermann B (1988) Effects of pollutants on fish. In: Salomons w, Dayne DL, Duursma EK, Förstror $Y$ (ods) Pollution of the North Sea: an assessment. SpringerVerlag, Berlin, p 612-623

Camus CA, Wolke RE (1991) Atypical hepatic vacuolated cell lesion in the white perch, Morone americana. Dis Aquat Org 11:225-228

De Veen JF (1971) Bot, een sportieve vis (The flounder, a sporting fish). Visserij 24:189-197 (in Dutch)

Fournie JW, Black JJ, Vethaak AD (1988) Exocrine pancreatic adenomas in the greater redhorse, Moxostoma valenciennesi Jordan, and in European flounder, Platichthys flesus (Linnaeus). J Fish Dis 11:445-448

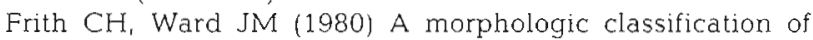
proliferative and neoplastic hepatic lesions in mice. J Environ Pathol Toxicol 3:329-351

Hendricks JD, Meyers TR, Shelton DW (1984) Histological progression of hepatic neoplasia in rainbow trout (Salmo gairdneri\}. Natl Cancer Inst Monogr 65:321-336

Hinton DE (1989) Environmental contamination and cancer in fish. Mar Environ Res 28:411-416

Hinton DE (1994) Cells, cellular responses, and their markers in chronic toxicity of fishes. In: Malins DC, Ostrander GK (eds) Aquatic toxicology: molecular, biochemical, and cellular perspectives. CRC Press, Boca Raton, FL, p $207-239$

Hinton DE, Laurén DJ (1990) Integrative histopathological approaches to detecting effects of environmental stressors on fishes. Am Fish Soc Symp 8:51-66

Johnson LL, Stehr CM, Olson OP, Myers MS, Pierce SM. Wigren CA, McCain BB, Varanasi U (1993) Chemical contaminants and hepatic lesions in winter flounder (Pleuronectes americanus) from the northeast coast of the United States. Environ Sci Technol 27:2759-2771

Köhler A (1989) Regeneration of contaminant-induced liver lesions in flounder-experimental studies towards the identification of cause-effect relationships. Aquat Toxicol 14:203-232

Malıns DC, McCain BB, Landahl JT, Myers MS, Krahn MM, Brown DW, Chan SL, Roubal WT (1988) Neoplastic and other diseases in fish in relation to toxic chemicals: an overview. Aquat Toxicol 11:43-67

Maronpot RR, Montgomery M, Boorman GA, McConnell EE (1986) National Toxicology Programme Nomenclature for hepatic proliferative lesions of rat. Toxicol Pathol 14: 263-273

Moore MJ, Smolowitz R, Stegeman JJ (1989) Cellular alterations preceding neoplasia in Pseudopleuronectes americanus from Boston harbour. Mar Environ Res 28:425-429
Moore MN (1992) Molecular and cellular pathology: summary. Mar Ecol Prog Ser 91:117-119

Murchelano RA, Wolke RE (1991) Neoplasms and nonneoplastic liver lesions in wintel flounder, Pseudopleuronectes americanus, from Boston Harbor, Massachusetts. Environ Health Perspect 90:17-26

Myers MS, Landahl JT, Krahn MM, McCain BB (1991) Relationships between hepatic neoplasms and related lesions and exposure to toxic chemicals in marine fish from the U.S. West Coast. Environ Health Perspect 90:7-16

Myers MS, Rhodes LD, McCain BB (1987) Pathologic anatomy and patterns of occurrence of hepatic lesions, and other idiopathic hepatic conditions in English sole (Parophrys vetulus) from Puget Sound, Washington. J Natn Cancer Inst 78:333-361

Myers MS, Stehr CS, Olson OP, Johnston LL, McCain BB, Chan SL, Varanasi U (1994) Relationships between toxicopathic hepatic lesions and exposure to chemical contaminants in English sole (Pleuronectes vetulus), starry flounder (Platichthys stellatus), and white croaker (Genyonemus lineatus) from selected marine sites on the Pacific Coast, U.S.A. Environ. Health Perspect 102:200-215

Schiewe MH, Weber DD, Myers MS, Jaques FJ, Reichert WL, Krone CA, Malins DC, MCCain BB, Chan SL, Varanasi U (1991) Induction of foci of cellular alteration and other hepatic lesisons in English sole (Parophrys vetulus) exposed to an extract of an urban marine sediment. Can J Fish Aquat Sci 48:1750-1760

Stehr CM, Johnston LL, Myers MS (1991) Severe hydropic degeneration in the liver of rock sole Lepidopsetta bilineata and starry flounder Platichthys stellatus from contaminated areas of Puget Sound. Proc Puget Sound Res '91 2:776

Stehr CM, Rhodes LD, Myers MS (1988) The ultrastructure and histology of hepatocellular carcinomas of English sole (Parophrys vetulus) from Puget Sound, Washington. Toxicol Pathol 16:418-431

Van Leeuwen P, Vethaak AD (1988) Growth of European flounder (Platichthys flesus) and common dab (Limanda limanda) in Dutch coastal waters with reference to healthy and diseased fish. ICES-C.M./G:54

Vethaak AD (1992a) Diseases of flounder (Platichthys flesus) in the Dutch Wadden Sea and their relation to stress factors. Neth J Sea Res 29:257-272

Vethaak AD (1992b) Gross pathology and histopathology in fish: summary. Mar Ecol Prog Ser 91:171-172

Vethaak AD, ap Rheinallt T (1992) Fish disease as a monitor of marine pollution: the case of the North Sea. Rev Fish Biol Fish 2:1-32

Vethaak AD, Bucke D, Lang $T$, Wester P, Jol JG, Carr M (1992) Fish disease monitoring along a pollution transect: a case study using dab (Limanda limanda) in the German Bight, North Sea. Mar Ecol Prog Ser 91:173-199

Vethaak A.D, Jol JG (1996) Diseases of flounder Platichthys flesus in Dutch coastal and estuarine waters, with particular reference to environmental stress factors. I. Epizootiology of gross lesions. Dis Aquat Org 26:81-97

Vogelbein WK, Fournie JW, Van Veld PA, Huggett RJ (1990) Hepatic neoplasms in the mummichog Fundulus heteroclitus from a creosote-contaminated site. Cancer Res 50:5978-5986

Wolke RE (1992) Piscine macrophage aggregates: a review A Rev Fish Dis 91-108

Wolke RE, Murchelano RA, Dicksteın CD, George CJ (1985) Preliminary evaluation of the use of macrophage aggregates (MA) as fish health monitors. Bull Environ Contam Toxicol 35:222-227 